\title{
Properties of Sweet Buttermilk Released from the Churning of Cream Separated from Sheep or Cow Milk or Sheep Cheese Whey: Effect of Heat Treatment and Storage of Cream
}

\author{
Lambros Sakkas $^{1}$ (D), Vasiliki Evageliou ${ }^{1}$, Panagiotis E. Igoumenidis ${ }^{2}$ (D) and Golfo Moatsou ${ }^{1, *(D)}$ \\ 1 Department Food Science and Human Nutrition, Agricultural University of Athens, 75 Iera Odos, \\ 11855 Athens, Greece; lasakkas@hotmail.com (L.S.); evageliou@aua.gr (V.E.) \\ 2 Department of Food Science and Technology, University of West Attica, 28 Agiou Spiridonos, \\ 12243 Egaleo, Greece; igoumenidisp@gmail.com \\ * Correspondence: mg@aua.gr
}

check for

updates

Citation: Sakkas, L.; Evageliou, V.; Igoumenidis, P.E.; Moatsou, G. Properties of Sweet Buttermilk Released from the Churning of Cream Separated from Sheep or Cow Milk or Sheep Cheese Whey: Effect of Heat Treatment and Storage of Cream. Foods 2022, 11, 465. https:// doi.org/10.3390/foods11030465

Academic Editor: Bianca Castiglioni

Received: 30 December 2021

Accepted: 3 February 2022

Published: 5 February 2022

Publisher's Note: MDPI stays neutral with regard to jurisdictional claims in published maps and institutional affiliations.

Copyright: (c) 2022 by the authors. Licensee MDPI, Basel, Switzerland. This article is an open access article distributed under the terms and conditions of the Creative Commons Attribution (CC BY) license (https:// creativecommons.org/licenses/by/ $4.0 /)$.

\begin{abstract}
The objective of the study was to compare the buttermilk released from the churning of sweet cream separated from sheep milk (BSM) or whey (BSW) with the buttermilk from sweet cow milk cream (BCM). Additional experimental factors were the heat treatment $\left(68^{\circ} \mathrm{C}\right.$ for 10 or $\left.30 \mathrm{~min}\right)$ and storage of cream (refrigeration or freezing). The composition of BSM was the most advantageous in terms of non-fat solids, protein - which was the most abundant solid component-casein, calcium and phosphorus contents. No significant differences were observed in the phospholipids (PL) content of BSM, BCM and BSW. Antioxidant potential and emulsion stability (ES) of BSM were the highest. The radical scavenging activity (RSA) of BSW was high opposite to chelating activity (CA). Some functional properties of BSW were similar to those of BSM and BCM. The freezing of cream affected the churning, the fat content, the soluble nitrogenous fraction at $\mathrm{pH} 4.6$ (WSN) and some functional properties of buttermilk, but not in a consistent manner. The properties of BSM were marginally affected or unaffected by the use of frozen cream. The freezing of whey cream caused significant changes $(p<0.05)$ in the protein profile and the functional behaviour of BSW. Cream heat treatment affected the WSN of BSW opposite to its sweet cream counterparts.
\end{abstract}

Keywords: sheep/cow buttermilk; whey buttermilk; frozen cream; thermized/pasteurized cream; antioxidant properties; minerals; phospholipids; functional properties

\section{Introduction}

Sweet or acidified buttermilk is the by-product of the butter making process and contains most of the ingredients of milk fat globule membrane (MFGM) and relatively small amounts of triglycerides, depending on the butter making conditions [1]. The non-acidic $\mathrm{pH}$ of sweet buttermilk is appropriate for most food formulae and is the main type of commercial buttermilk [2-4]. The composition of sweet buttermilk is similar to skim milk in terms of gross composition and its major components are the non-fat components of churned cream, i.e., caseins, serum/whey proteins, lactose and minerals [2,5]. The dry matter ranges from 8 to $12 \%$ and the fat on dry matter from 4.6 to $14.5 \%$ [3]. Buttermilk contains parts and components of MFGM, such as proteins and polar lipids [3,6-10], in quantities affected by the conditions of the heat treatment and churning of cream $[2,5,11,12]$. The concentration of polar lipids can be $2 \%$ on dry matter or $80-125 \mathrm{mg}$ per $\mathrm{g}$ fat of buttermilk, that is much higher than the respective $0.28 \%$ of skim milk and $2.7-4.8 \mathrm{mg}$ per $\mathrm{g}$ of full-fat milk [6,12]. Due to the phospholipids (PL), buttermilk exhibits emulsifying properties, considerable water holding capacity and lower foaming capacity than skimmed milk $[2,13,14]$. The biological properties of buttermilk and MFGM, which are mainly attributed to sphingomyelin, PL, sialic acid and gangliosides, are remarkable. Protective activity against infections and bacterial toxins, reduction in cholesterol levels, anticancer 
and antioxidant potential, regulatory role at the cellular level, positive effect on the development and function of nerve tissue, hair and skin, prevention of age-related cognitive decline and muscle loss, have been reported [4,6,12,15-20].

The multi-functionality of buttermilk is exploited in several applications of food technology, e.g., for the improvement of water holding capacity and texture and the protection against lipid oxidation of bakery, confectionary and sauce-type products [3,4]. In the dairy industry, buttermilk is used for the production of beverages, as an ingredient of ice cream, as an additive to increase the thermal stability of reconstituted condensed milk and for the improvement of structure, sensory characteristics and yield of low-fat yogurt and cheese [3,11,21-25]. Components of buttermilk and MFGM are involved in the formation of liposomes for the delivery of drug or food additives. Finally, due to the presence of sphingomyelin, which is not present in plant polar lipids, buttermilk ingredients are used in infant formulae and cosmetics $[8,19,20]$.

There is a limited number of publications on the properties and technological behaviour of buttermilk or MFGM preparations from differently treated cream or from different types of cream of cow origin. It has been reported that the increase in the intensity of cream heat treatment decreases the soluble proteins $[5,24]$ and increases the fat content $[26,27]$ or the percentage of PL in fat of buttermilk [5]. It affects adversely the rennet clotting behaviour of milk supplemented with buttermilk or the rheological properties of the resultant gel $[5,24,26,27]$; although, a similar effect was not observed in milk supplemented with MFGM fractions with variable thermal history [28]. Sweet cow cream and whey cream buttermilk differ in respect to protein profile, lactose content and organoleptic characteristics [29], protein content [30] or colour [31]. Whey buttermilk exhibits greater emulsifying and lower foaming ability compared with its sweet cream counterpart [32], while lower emulsifying capacity in MFGM fractions from whey-derived buttermilk has been observed [32].

Publications for buttermilk from non-cow milk are scarce, despite the technologically interesting features of their lipid fraction and structural elements [33-35]. In brief, the mean diameter of sheep milk fat globule (MFG) ranges within 3-3.8 $\mu \mathrm{m}$, which is lower than the mean diameter of cow MFG. The concentration of total polar lipids expressed as percentage of milk fat ranges within $0.38-0.70$ and $0.36-0.82 \%$, for sheep and cow MFG, respectively. There are also differences in the structural characteristics of the MFGM. There is a higher contribution of monounsaturated and a lower contribution of saturated fatty acids in the polar lipid fraction of sheep milk (SM) compared with cow milk (CM). Average cholesterol content of sheep and cow MFGM is 1.8 and $1.7 \mathrm{mg} / \mathrm{m}^{2}$, respectively. Sheep MFGM contains more sphingomyelin than cow MFGM and has a lower cholesterol to sphingomyelin ratio, i.e., 2.8 and $3.6 \mathrm{~mol} / \mathrm{mol}$, respectively. Gangliosides in the outer surface of sheep MFGM are considerably less than in CM. The diameter of casein micelle of SM is greater than that of CM, i.e., $170-220 \mathrm{~nm}$ and $150-180 \mathrm{~nm}$, respectively, and the most abundant casein in SM is $\beta$-casein [33-35].

Hamad et al. [36] investigated the use of goat and sheep buttermilk in the manufacture of the fermented dairy product Jameed. Lamothe et al. [37] found that the PL to protein ratio was higher in goat buttermilk than in its cow counterpart. Parrón et al. [38] reported similar protein profile and lactose and protein contents for cow and sheep buttermilk, but higher lipid content for the latter. The same group [38-40] reported a higher dosedependent antiviral activity of sheep buttermilk and its components compared with its cow counterpart. The gross composition and cheese making potential of sweet sheep and goat buttermilk alone or in mixtures with milk with variable fat content has been investigated by Sakkas et al. [24]. The same group [25] studied the properties and ripening course of semi-hard cheese from reduced-fat SM supplemented with sweet sheep buttermilk.

The aim of the present study was to examine the effect of cream origin and treatment on the compositional, physical and functional properties of sweet buttermilk. The main subject was the sweet buttermilk released during the churning of cream separated from SM or sheep cheese whey (SW). The experimental factors were the heat treatment of 
cream - thermization or pasteurization - and the storage of heat-treated sweet cream before low-temperature ripening and churning, that is, immediate use or freezing for five months. For comparison, sweet buttermilk from CM was manufactured and analysed under the same conditions. Among the new elements of the present work are the study of SW buttermilk, the use of frozen cream and the comparative presentation of the effect of manufacturing conditions on buttermilk resulting from different kinds of cream.

\section{Materials and Methods}

\subsection{Experimental Design and Sampling Scheme}

The design of the experiments, the types of manufactured buttermilks and the codes of collected samples are schematically presented in Figure 1. In detail, the experiments were performed as follows:

i. $\quad$ Preparation of creams: Creams were obtained by skimming thermized SM and CM and by double skimming pasteurized SW. SW was collected from the manufacture of a hard-type cheese made from curd heated up to $50{ }^{\circ} \mathrm{C}$. All cream types were standardized to $40 \%$ fat and were divided in two equal portions of $2.5 \mathrm{~kg}$ each. The first portion was thermized at $68^{\circ} \mathrm{C}$ for $10 \mathrm{~min}$ and the second was pasteurized at $68^{\circ} \mathrm{C}$ for $30 \mathrm{~min}$. After rapid cooling down to $10{ }^{\circ} \mathrm{C}$, creams were either ripened at $<6{ }^{\circ} \mathrm{C}$ for $20 \mathrm{~h}$ or kept frozen at $<-20{ }^{\circ} \mathrm{C}$ for five months (frozen creams). Three replicates were performed for each combination of the experimental factors $(\mathrm{CM}$, SM and SW cream, thermized or pasteurized cream, fresh or frozen cream).

ii. Buttermilk from non-frozen cream: After ripening at low temperature, creams were churned to butter and buttermilk at $6{ }^{\circ} \mathrm{C}$ using an overhead mixer. Buttermilk was filtrated with sterilized cloth-filter before collection and coded as follows: BCMTbuttermilk from CM-thermized cream; BCMP_-buttermilk from CM-pasteurized cream; BSMT-buttermilk from SM-thermized cream; BSMP-buttermilk from SM-pasteurized cream; BSWT-buttermilk from SW-thermized cream; BSWPbuttermilk from SW-pasteurized cream.

iii. Buttermilk from frozen cream: Frozen creams were defrosted at $6{ }^{\circ} \mathrm{C}$ within 2 days and remained at room temperature for 2 hours before heating in a water bath at $30{ }^{\circ} \mathrm{C}$ under gentle stirring for a few minutes. Then, remained at room temperature and stirred periodically, till they reached $24{ }^{\circ} \mathrm{C}(\mathrm{CM}, \mathrm{SM})$ or $16{ }^{\circ} \mathrm{C}(\mathrm{SW})$. Finally, all types of cream were rapidly cooled down to $10^{\circ} \mathrm{C}$ and ripened at $<6{ }^{\circ} \mathrm{C}$ for $20 \mathrm{~h}$ prior to churning. The temperature sequence for frozen creams had been developed in preliminary experiments. Churning of creams to butter and buttermilk took place at $6{ }^{\circ} \mathrm{C}$ using an overhead mixer. Buttermilk was collected after filtration and coded as follows: BCMTF-buttermilk from CM-thermized and frozen cream; $\mathrm{BCMPF}$-buttermilk from CM-pasteurized and frozen cream; BSMTF-buttermilk from SM-thermized and frozen cream; BSMPF-buttermilk from SM-pasteurized and frozen cream; BSWTF-buttermilk from SW-thermized and frozen cream; BSWPF-buttermilk from SW-pasteurized and frozen cream.

\subsection{Analysis of Milk, Whey, Cream and Buttermilk}

The gross composition of milk, whey and buttermilk was estimated by the FT-IR analyser Milkoscan-FT120 (Foss, Hillerød, Denmark). Titratable acidity and pH of milk, whey, cream and buttermilk were determined by means of the Dornic method and a $\mathrm{pH}$ meter, respectively [41]. Fat content of milk, whey and buttermilk was estimated by the Gerber method [42]. The fat content of cream was determined in a 1:1 mixture of cream and distilled water using a "Koehler" butyrometer. 


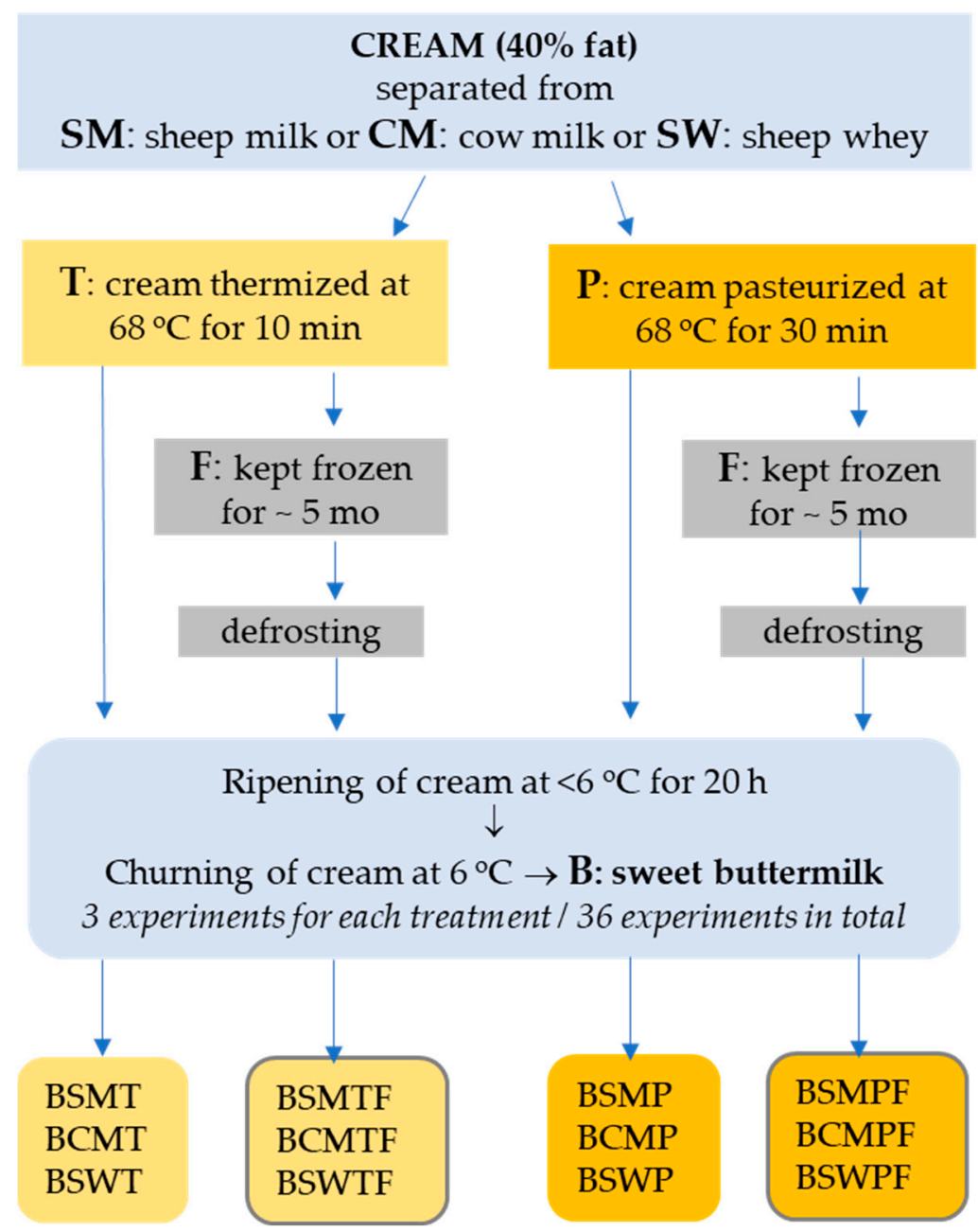

Figure 1. Design of the experiments, types of manufactured buttermilks and codes of collected buttermilk samples. BSMT_-buttermilk from SM-thermized cream; BCMT_-buttermilk from CM-thermized cream; BSWT-buttermilk from SW-thermized cream; BSMP_-buttermilk from SM-pasteurized cream; BCMP_-buttermilk from CM-pasteurized cream; BSWP_-buttermilk from SW-pasteurized cream. $\mathrm{F}$ at the end of a buttermilk code indicates the use of frozen cream.

\subsection{Analysis of Buttermilk Nitrogenous Fractions}

Protein and acid-soluble protein of buttermilk were determined in duplicate by the Kjeldahl method. Buttermilk water (acid)-soluble nitrogen fraction (WSN) was prepared by acidification at $\mathrm{pH} 4.6$ and total nitrogen (TN) and WSN contents were assessed in duplicate by the Kjeldahl method [41]. The concentration of major whey proteins in buttermilks was estimated by analysis of WSN in duplicate by means of reversed-phase high-performance liquid chromatography (RP-HPLC) as described by Sakkas et al. [24].

\subsection{Biofunctional Potential of Buttermilk}

\subsubsection{Minerals}

The determination of calcium, sodium, potassium and magnesium contents in the ash fraction of buttermilks was performed by the atomic absorption spectrometric method (AAS) [43]. The phosphorus content of buttermilk was assessed by molecular absorption spectrometry (MAS) [44]. The stock dilution for AAS analysis was $25 \mathrm{mg}$ of buttermilk ash in one $\mathrm{mL}$ of $25 \%(v / v) \mathrm{HNO}_{3}$ made up to $100 \mathrm{~mL}$ with Milli-Q water. The stock dilution for the MAS analysis was $25 \mathrm{mg}$ of buttermilk ash in $2.5 \mathrm{~mL}$ of $\mathrm{HCl}(36 \mathrm{~g} / \mathrm{L})$ made up to $100 \mathrm{~mL}$ with Milli-Q water. 


\subsubsection{Antioxidant Activity}

Two different assays were used for the evaluation of buttermilk antioxidant activity. 2,2-diphenyl-1-picrylhydrazyl (DPPH.) radical scavenging activity (RSA) was determined in triplicate [45], in a mixture of $150 \mathrm{mg}$ of buttermilk or methanol (control) or Trolox and $850 \mu \mathrm{L}$ of $0.1 \mathrm{mM}$ DPPH. in methanol. The determination of $\mathrm{Fe}^{2+}$-chelating activity (CA) was performed in triplicate as described by Moschopoulou et al. [45], adjusting the concentration of the buttermilk in the mixture to that reported by Conway et al. [46]. Buttermilk was diluted 1:75 in Milli-Q water, centrifuged (1000×g for $10 \mathrm{~min}$ ) and the supernatant was filtered through $0.45 \mu \mathrm{m}$ poly(vinylidene fluoride) Whatman filter (PVDF). Then, $700 \mu \mathrm{L}$ of filtrate or ultra-pure water (control) or ethylenediaminetetraacetic acid (EDTA) were mixed with $70 \mu \mathrm{L}$ of $1.2 \mathrm{mM} \mathrm{FeSO}_{4}$ in Eppendorf tubes. After thorough stirring, the mixture was incubated for $30 \mathrm{~min}$ in the dark, at room temperature, and $70 \mu \mathrm{L}$ of $2.4 \mathrm{mM}$ ferrozine was added. Tubes were vortexed for $2 \mathrm{~min}$ and $240 \mu \mathrm{L}$ were transferred in 96-well microplates. After stirring for $3 \mathrm{~min}$, an absorbance at $562 \mathrm{~nm}$ was recorded.

\subsubsection{Phospholipids (PL)}

The buttermilk fat extraction was performed as described by Sakkas et al. [25] with some modifications: $15 \mathrm{~g}$ of buttermilk, $15 \mathrm{~mL}$ of hexane and $10 \mathrm{~mL}$ of isopropanol were used, the final mixture was centrifuged at $1000 \times g$ for $10 \mathrm{~min}$ at $20^{\circ} \mathrm{C}$, re-extraction of the bottom layer was not performed and the duration of holding at $102{ }^{\circ} \mathrm{C}$ was $30 \mathrm{~min}$. The determination of PL content was performed according to Sakkas et al. [25].

\subsection{Particle Size Distribution in Buttermilk}

Buttermilks were heated at $40{ }^{\circ} \mathrm{C}$ for $60 \mathrm{~min}$ prior to analysis with a SALD-2300 Shimadzu laser diffraction particle size analyser (Shimadzu Corporation, Tokyo, Japan). Buttermilks were dispersed in a sampler water bath where a laser beam was transmitted. The intensity and the angle of the scattered light emitted by the particle groups were detected and used for the calculation of particle size distribution.

\subsection{Functional Properties of Buttermilk}

\subsubsection{Sample Preparation}

Prior to measurements, all samples were brought to $3 \% w / w$ protein concentration with either dilution with distilled water (sweet cream buttermilks) or evaporation (whey cream buttermilks). Frozen whey buttermilk samples $\left(-4^{\circ} \mathrm{C}\right)$ were freeze dried under constant vacuum conditions at $-10^{5} \mathrm{~Pa}$ and $-40^{\circ} \mathrm{C}$ for $24 \mathrm{~h}$ using a UNICRYO MC2L (Munich, Germany) apparatus. For viscosity measurements, evaporation of whey buttermilk samples was performed by means of an IKA Labortechnik Rotary Evaporator RV 06-ML (Staufen, Germany) at temperatures below $45{ }^{\circ} \mathrm{C}$. Measurements for all studied functional properties were performed in two $\mathrm{pH}$ values, namely 4.5 and 6.6. $\mathrm{pH}$ was adjusted by 0.1 and $1 \mathrm{M} \mathrm{HCl}$ or $\mathrm{NaOH}$ solutions.

\subsubsection{Viscosity}

Viscosity of all samples at both $\mathrm{pH}$ values was measured at room temperature $\left(20{ }^{\circ} \mathrm{C}\right)$ with an Anton Paar MCR 102 Rheometer (Anton Paar GmbH, Graz, Austria), using a cone-plate geometry. The cone had a diameter of $50 \mathrm{~mm}$ and an angle of $1^{\circ}$, while the gap between the cone and the plate was set at $0.101 \mathrm{~mm}$. The temperature of each buttermilk sample, on the rheometer plate, was equilibrated at $20{ }^{\circ} \mathrm{C}$ for $5 \mathrm{~min}$ prior to measurement. Shear rates from 1 to $100 \mathrm{~s}^{-1}$ were applied during each measurement, to obtain a flow curve. For clarity reasons, the apparent viscosity values presented (in $\mathrm{mPa} \cdot \mathrm{s}$ ) correspond to $100 \mathrm{~s}^{-1}$ rate. Three measurements were performed for each sample and mean viscosity values were calculated. 


\subsubsection{Emulsifying Properties}

Oil-in-water (o/w) emulsions were prepared by mixing $10 \mathrm{~mL}$ of corn oil and $40 \mathrm{~mL}$ of each sample at room temperature using a CAT X 120 homogeniser (M. Zipperer GmbH, Ballrechten-Dottingen, Germany) at 22,000 rpm for $2 \mathrm{~min}$. Then, $10 \mathrm{~mL}$ of each emulsion were transferred to a $15 \mathrm{~mL}$ centrifuge tube. The tube was sealed tightly and stored at $4{ }^{\circ} \mathrm{C}$. The determination of the emulsion's stability (ES) was based on its height change due to phase separation during storage, as described by Huang et al. [47]. Thus, the initial height of each emulsion upon preparation $\left(\mathrm{H}_{0}\right)$ and the height of the remaining emulsified layer volume after one day of storage $\left(\mathrm{H}_{\text {storage }}\right)$ were recorded. ES was determined by the following equation: $\mathrm{ES}(\%)=\left(\mathrm{H}_{\text {storage }} / \mathrm{H}_{0}\right) \times 100$. For each $\mathrm{pH}$, three emulsions were formed and measured.

\subsubsection{Foaming Properties}

For foam formation, $30 \mathrm{~mL}\left(\mathrm{~V}_{\mathrm{s}}\right)$ of each sample at both $\mathrm{pH}$ values were stirred with a CAT X 120 homogeniser (M. Zipperer GmbH, Ballrechten-Dottingen, Germany) at 22,000 rpm for $3 \mathrm{~min}$ and then transferred into a graduated cylinder. The initial volume of the foam $\left(\mathrm{V}_{\mathrm{f}}\right)$ was measured, and foaming ability (FA) was calculated as follows: $\mathrm{FA}(\%)=\mathrm{V}_{\mathrm{f}} / \mathrm{V}_{\mathrm{s}}$. Measurements were repeated three times per $\mathrm{pH}$ value.

\subsubsection{Protein Solubility}

Each sample at both $\mathrm{pHs}$ was centrifuged at $12,000 \times \mathrm{g}$ for $15 \mathrm{~min}$ at $25^{\circ} \mathrm{C}(\mathrm{Z} 326 \mathrm{~K}$, Hermle Labortechnik GmbH, Wehingen, Germany). The supernatant was collected and analysed for its protein content with the Kjeldahl method. Protein solubility (PS) was calculated by the following equation: PS $(\%)=($ protein content of supernatant $/ 3) \times 100$.

\subsection{Statistical Analysis}

Thirty-six buttermilks were analysed and statistical analysis of the data was carried out using the Statgraphics Centurion XVI (Manugistics, Inc., Rockville, MA, USA). The effects of cream origin, cream heat treatment and cream storage and their interactions were assessed by multifactor analysis of variance (ANOVA). The significant differences between means were investigated by the least significance method (LSD) and a significance value of 0.05 . Correlation coefficients amongst variables were investigated by means of simple linear regression.

\section{Results and Discussion}

\subsection{Manufacturing Parameters}

The average composition of raw SM used for the preparation of cream was as follows: fat $6.21 \pm 0.59 \%$, protein $5.43 \pm 0.17 \%$, lactose $4.64 \pm 0.05 \%$, acidity $19.08 \pm 1.01 \%$ lactic acid (LA) and pH $6.68 \pm 0.04$. The respective parameters for raw CM were as follows: fat $3.34 \pm 0.30 \%$, protein $3.11 \pm 0.05 \%$, lactose $4.43 \pm 0.07 \%$, acidity $13.54 \pm 0.97 \%$ LA and $\mathrm{pH} 6.66 \pm 0.06$. The composition of SW was as follows: fat $1.37 \pm 0.17 \%$, protein $1.12 \pm 0.03 \%$, total solids $8.96 \pm 0.27 \%$, acidity $9.65 \pm 0.60 \%$ LA and pH $6.44 \pm 0.04$.

The conditions of heat treatment did not affect the acidity and the $\mathrm{pH}$ of the cream. The $\mathrm{pH}$ of sheep, cow and whey cream was $6.76 \pm 0.04,6.79 \pm 0.09$ and $6.46 \pm 0.05$, respectively. The acidity expressed as \% LA was $0.091 \pm 0.002,0.074 \pm 0.003$ and $0.068 \pm 0.007$, respectively. The $\mathrm{pH}$ was not in accordance with \% acidity, due to the interference of caseins in the estimation of the latter. Both the acidity and the $\mathrm{pH}$ of whey cream were statistically significantly lower $(p<0.05)$ than those of cream prepared from milk.

The average initial temperature of all cream types, i.e., 36 experiments, was $5.8 \pm 0.20^{\circ} \mathrm{C}$. Table 1 is a synopsis of the manufacturing conditions/parameters for the various types of buttermilks of the present study grouped according to cream origin and preservation. The heat treatment of cream - thermization or pasteurization-had no significant effect. The cream origin and storage and their interaction affected statistically significantly $(p<0.05)$ the churning duration (min), the final temperature at the end of churning and the buttermilk 
yield, expressed as percentage of the quantity of the churned cream. The duration of churning is an important parameter of butter making and affects the composition of buttermilk [1]. The churning time ( $\mathrm{min})$ of CM cream was significantly higher $(p<0.05)$ compared with both types of cream of sheep origin. Churning duration was strongly positively correlated with the cream's $\mathrm{pH}(r=0.900)$ but the opposite was true for the $\%$ acidity $(r=0.383)$. The use of frozen cream decreased dramatically $(p<0.05)$ the churning duration and in turn decreased the yield statistically significantly $(p<0.05)$. Churning starts with the disruption of the MFGM. Apparently, the temperature sequence applied in frozen cream had destabilized the surface of MFG prior to churning without any visible change in cream structure.

Table 1. Parameters of the manufacture of various types of buttermilk. Mean and standard deviation (sd) of six experiments. BSM-buttermilk from sheep milk cream; BCM-buttermilk from cow milk cream; BSW-buttermilk from sheep cheese whey cream; F at the end of a code indicates the use of frozen cream.

\begin{tabular}{|c|c|c|c|c|c|c|}
\hline \multirow[t]{2}{*}{ Cream } & \multicolumn{2}{|c|}{ Churning (min) } & \multicolumn{2}{|c|}{ Final $\mathrm{T}\left({ }^{\circ} \mathrm{C}\right)$} & \multicolumn{2}{|l|}{ Yield (\%) } \\
\hline & Mean & sd & Mean & sd & Mean & sd \\
\hline \multicolumn{7}{|c|}{ Non-frozen } \\
\hline BSM & $14.75 \mathrm{~b}$ & 0.61 & $7.67 \mathrm{~b}$ & 0.31 & 47.84 & 3.12 \\
\hline BCM & $17.83 \mathrm{c}$ & 1.13 & $10.42 \mathrm{c}$ & 0.85 & 48.54 & 0.48 \\
\hline BSW & $9.71 \mathrm{a}$ & 0.83 & $6.8 \mathrm{a}$ & 0.45 & 48.46 & 0.72 \\
\hline \multicolumn{7}{|l|}{ Frozen } \\
\hline BSMF & $1.0 \mathrm{a}^{*}$ & 0.16 & $6.45 a *$ & 0.25 & $41.58 \mathrm{a} *$ & 1.78 \\
\hline BCMF & $4.54 b^{*}$ & 2 & $6.48 a^{*}$ & 0.29 & $44.79 \mathrm{~b}$ * & 0.65 \\
\hline BSWF & $1.67 \mathrm{a}^{*}$ & 0.58 & $6.47 \mathrm{a}$ & 0.05 & $44.45 b^{*}$ & 2.86 \\
\hline
\end{tabular}

$\mathrm{a}-\mathrm{c}$-statistically significant differences (LSD, $p<0.05$ ) within the group of non-frozen or frozen cream * - significant difference (LSD, $p<0.05)$ between buttermilks of the same type from non-frozen or frozen cream.

\subsection{Compositional Parameters}

Compositional parameters of various types of buttermilk grouped according to cream origin and preservation are shown in Table 2; the heat treatment of cream was not a statistically significant factor $(p>0.05)$.

Table 2. Composition of various types of buttermilk. Mean and standard deviation (sd) of six experiments. BSM — buttermilk from sheep milk cream; BCM—buttermilk from cow milk cream; BSW-buttermilk from sheep cheese whey cream; $F$ at the end of a code indicates the use of frozen cream; LA—lactic acid; TS—total solids; SNF—solids (non-fat).

\begin{tabular}{|c|c|c|c|c|c|c|c|c|c|c|c|c|c|c|c|c|c|c|}
\hline \multicolumn{7}{|c|}{ Cream } & \multicolumn{12}{|c|}{ FTIR Analysis } \\
\hline \multicolumn{3}{|c|}{$\mathrm{pH}$} & \multicolumn{2}{|l|}{$\%$ LA } & \multicolumn{2}{|l|}{$\%$ Fat $^{1}$} & \multicolumn{2}{|l|}{$\%$ Fat } & \multicolumn{2}{|c|}{$\%$ Protein } & \multicolumn{2}{|l|}{ \%Lactose } & \multicolumn{2}{|l|}{$\% \mathrm{TS}$} & \multirow{2}{*}{$\begin{array}{l}\% \text { SNF } \\
\text { Mean }\end{array}$} & \multicolumn{3}{|c|}{$\mathrm{P} / \mathrm{F}$} \\
\hline & Mean & sd & Mean & sd & Mean & sd & Mean & sd & Mean & sd & Mean & sd & Mean & sd & & sd & Mean & sd \\
\hline Non & frozen & & & & & & & & & & & & & & & & & \\
\hline BSM & $6.75 \mathrm{~b}$ & 0.03 & $0.20 \mathrm{c}$ & 0.01 & $2.78 \mathrm{c}$ & 0.2 & $2.86 \mathrm{c}$ & 0.23 & $5.51 \mathrm{c}$ & 0.09 & $5.04 \mathrm{a}$ & 0.05 & $13.98 \mathrm{c}$ & 0.30 & $11.11 \mathrm{c}$ & 0.10 & $1.93 \mathrm{~b}$ & 0.16 \\
\hline BCM & $6.72 \mathrm{~b}$ & 0.17 & $0.13 b$ & 0.01 & $0.91 \mathrm{a}$ & 0.35 & $1.02 \mathrm{a}$ & 0.29 & $3.28 \mathrm{~b}$ & 0.07 & $4.99 \mathrm{a}$ & 0.08 & $10.34 \mathrm{~b}$ & 0.26 & $9.35 \mathrm{~b}$ & 0.12 & $3.42 \mathrm{c}$ & 0.91 \\
\hline $\begin{array}{l}\text { BSW } \\
\quad \text { Fr }\end{array}$ & $\begin{array}{l}6.43 \text { a } \\
\text { ozen }\end{array}$ & 0.04 & $0.11 \mathrm{a}$ & 0.004 & $1.99 \mathrm{~b}$ & 0.32 & $2.21 \mathrm{~b}$ & 0.35 & $2.48 \mathrm{a}$ & 0.02 & $5.33 \mathrm{~b}$ & 0.12 & $9.79 \mathrm{a}$ & 0.35 & $8.27 \mathrm{a}$ & 0.12 & $1.15 \mathrm{a}$ & 0.2 \\
\hline BSMF & $6.55 a, b$ * & 0.04 & $0.18 \mathrm{c}$ & 0.01 & $1.81 b^{*}$ & 0.31 & $1.95 b^{*}$ & 0.28 & $5.49 \mathrm{c}$ & 0.23 & $5.20 \mathrm{~b}^{*}$ & 0.09 & $\underset{*}{13.22 ~ c}$ & 0.48 & $11.25 \mathrm{c}$ & 0.21 & $2.86 b^{*}$ & 0.37 \\
\hline BCMF & $6.61 \mathrm{~b}$ & 0.07 & $0.13 \mathrm{~b}$ & 0.01 & $3.36 c^{*}$ & 0.63 & $3.39 c^{*}$ & 0.66 & $3.06 b^{*}$ & 0.08 & $4.81 \mathrm{a}^{*}$ & 0.10 & $\underset{*}{12.29} \mathrm{~b}$ & 0.57 & $8.94 b^{*}$ & 0.14 & $0.93 a$ * & 0.19 \\
\hline BSWF & $6.49 \mathrm{a}$ & 0.07 & $0.11 \mathrm{a}$ & 0.01 & $0.84 \mathrm{a}^{*}$ & 0.25 & $1.03 \mathrm{a}^{*}$ & 0.29 & $2.43 \mathrm{a}$ & 0.07 & $5.27 \mathrm{~b}$ & 0.12 & $8.49 a^{*}$ & 0.32 & $8.15 \mathrm{a}$ & 0.14 & $2.62 b^{*}$ & 1.15 \\
\hline
\end{tabular}

Buttermilk composition was statistically significantly affected $(p<0.05)$ by the cream origin. The interaction of cream origin and cream preservation affected significantly $(p<0.05)$ the majority of compositional parameters especially those of CM buttermilk. The 
significant $(p<0.05)$ decrease in $\mathrm{pH}$ in SW buttermilk and in buttermilks from frozen creams can be assigned to manufacturing particularities such as the lower initial $\mathrm{pH}$ and the double skimming of whey cream or the additional temperature sequence applied in frozen cream.

Since all cream types had similar fat content and initial temperature, an increase in fat content in buttermilk coincides with high liquid fat content in cream during churning, rapid churning or small-sized MFG [1]. The higher fat content of SM buttermilks from non-frozen SM and SW cream was in accordance with the smaller size of sheep MFG [34,35] and the faster breaking down compared with its cow counterpart (Table 1). The fat content of buttermilks was substantially changed by the use of frozen cream but not in the same direction for the three types of buttermilk. The fat content of CM buttermilk increased opposite to those of sheep origin. The rapid churning of frozen cream (Table 1) is expected to increase the fat content [1], as observed in the BCMF in the present study (Table 2). On the contrary, under the same conditions, the fat content of BSMF and BSWF, that is, of buttermilks of sheep origin, decreased. The different behaviour of both types of sheep frozen creams indicates the involvement of factors that are specific for SM fat. Interestingly, SM lacks agglutinins that induce flocculation of MFG [48]. To our knowledge, there is no relevant scientific information for the churning of frozen cream of sheep origin. The significant change $(p<0.05)$ of fat content of buttermilks from frozen creams affected accordingly the concentration of the remaining solids. However, the non-fat solids (SNF) were significantly affected only in CM buttermilk $(p<0.05)$.

As reported earlier, the types of buttermilks of the present study differed significantly in terms of composition although they came from creams with the same fat content. The milk origin also induced statistically significant differences between sweet cream buttermilks (Table 2). The greatest part of total solids of BCM was lactose, with $43.8 \pm 5.08 \%$ on average-that is, $48.3 \pm 1.58$ and $39.2 \pm 2.13 \%$ of total solids, for buttermilk from non-frozen and frozen cream, respectively. Proteins were the second most abundant group of constituents, i.e., $31.7 \pm 0.94$ and $24.9 \pm 1.63 \%$ of total solids, respectively. On average, protein and lactose expressed on the SNF of BCM were $34.6 \pm 0.69$ and $53.6 \pm 0.59 \%$, respectively. The composition of sweet buttermilk of cow origin has been estimated in several studies. In general, buttermilk contains $8-12 \%$ total solids and $4.6-14.5 \%$ lipids on dry matter [3]. Sodini et al. [2] reported that 48.7-53.8\%, 31.5-33.5\% and 5.7-13.1\% of the buttermilk total solids are lactose, protein and lipids, respectively. According to Morin et al. [49], 30.3\% and $8.41 \%$ of dry matter are proteins and fat, while the same group [30] found that $25 \%$ of dry matter consisted of proteins and $12.2 \%$ of lipids with a total solid content of $11.74 \pm 0.59 \%$. In the study of Gassi et al. [5], the total solids of sweet cream buttermilk ranged from 8.88 to $9.16 \%$, fat from 0.45 to $0.54 \%$ and protein from 2.78 to $2.94 \%$. Buttermilk prepared under laboratory conditions in the study of Barry et al. [50] consisted of $11.1 \%$ total solids, $2.8 \%$ fat, $3.36 \%$ protein and $4.23 \%$ lactose. Lambert et al. [51] found that the average total solids content of industrial whole buttermilks was low, i.e., $8.7 \pm 0.8 \%$, protein $2.9 \pm 0.3 \%$ and total lipids $0.9 \pm 0.4 \%$.

As shown in Table 2, BSM had significantly higher $(p<0.05)$ mean total solids-close to $14 \%$-due to substantially higher protein and fat content compared with its cow counterpart (BCM). In contrast to BCM, proteins were the most abundant group of solid components of BSM. In particular, $40.5 \% \pm 1.33 \%, 37.7 \pm 2.19 \%$ and $17.6 \pm 3.33 \%$ of dry matter were protein, lactose and fat, respectively. Interestingly, $49.2 \pm 0.98$ and $45.8 \pm 1.01 \%$ of SNF of BSM were proteins and lactose, respectively. Information for the composition of sheep buttermilk is scarce. Recently, Sakkas et al. [24] studied the cheesemaking properties of sweet cream buttermilk of sheep or goat origin. The average total solids content of SM buttermilk was $17.1 \%$ due to a higher fat content $(6.85 \%)$ compared with the present study; however, SNF were $10.25 \%$. Protein content was $4.96 \%$ and lactose $4.80 \%$ or $48.4 \%$ and $46.8 \%$ of SNF similarly to the estimations of the present study. Higher lipid content for sheep sweet buttermilk powder compared with that of cow origin-20\% vs. $15.5 \%$ - has also been reported by Parrón et al. [38]. In contrast to our findings, they found that protein 
was lower than lactose content, i.e., 30.5 and $39.5 \%(w / w)$, respectively, and similar to the respective contents of 27.5 and $39 \%(w / w)$ estimated in cow sweet buttermilk powder. Higher concentrations of total solids and proteins have also been reported for sheep buttermilk from acidified cream compared with a similar preparation from CM [36]. The gross composition of the former was $7.8 \%$ dry matter, $0.7 \%$ fat and $5.10 \%$ proteins and the respective contents of the latter were $6.7,0.25$ and $3.25 \%$, respectively.

BSW had the lowest total solids, protein and SNF contents among the three buttermilk types of the present study (Table 2). Mean fat content on dry matter (total solids) of BSW was $17.3 \pm 6.1 \%$ and similar to $17.6 \pm 3.32 \%$ estimated for BSM. However, the major solid component of BSW was lactose, which was twice the protein content. Two thirds of SNF was lactose, i.e., protein content was $29.9 \pm 0.62 \%$ and lactose was $64.5 \pm 0.68 \%$ of SNF. To our knowledge, there are no reports for buttermilk from SW cream. There are studies that exhibit the differences between the compositional profile of sweet cream and whey buttermilk of cow origin. The dry matter of whey buttermilk has been estimated as $7.61 \pm 0.92 \%$, that is two thirds of that of regular sweet buttermilk. Protein was $0.99 \pm 0.02 \%$, approximately one third of that of regular buttermilk [30]. In the study of Sodini et al. [2], 63.4\% of the dry matter of whey buttermilk was lactose, 15.5\% lipids and 15.5\% proteins; the latter was half the protein content of the sweet cream buttermilk analysed in parallel. Moreover, the whey buttermilk had a $\mathrm{pH}$ of 5.98-lower than $\mathrm{pH}$ 6.46-6.61 of the regular buttermilk. Total solids content of whey buttermilk in the study of Costa et al. [52] was 8.05\%, on average, and proteins and lipids were $2 \%$ and $1.31 \%$, respectively. Approximately $40 \%$, $35 \%$ and $11 \%$ of the dry matter of sweet cream buttermilk was lactose, protein and lipids, respectively, and the respective contents in whey buttermilk were 60, 20 and 11\% [29].

\subsection{Nitrogenous Fractions}

According to multifactor ANOVA, the various expressions of the concentration of nitrogenous fractions of buttermilks were statistically significantly $(p<0.05)$ affected by the three experimental factors of the study (Table 3). Figure 2 is a detailed presentation of the indices of the nitrogenous soluble fraction of the buttermilks.

Table 3. Nitrogenous fractions of various types of buttermilk. Mean and standard error (se) of the experiments $(n)$. BSM-buttermilk from sheep milk cream; BCM-buttermilk from cow milk cream; BSW-buttermilk from sheep cheese whey cream; NF and F-buttermilk from non-frozen and frozen cream, respectively; $\mathrm{T}$-cream thermized at $68{ }^{\circ} \mathrm{C}$ for $10 \mathrm{~min}$; $\mathrm{P}$-cream pasteurized at $68^{\circ} \mathrm{C}$ for $30 \mathrm{~min}$; INSP_protein insoluble at $\mathrm{pH} 4.6$; $\mathrm{SP}$-soluble proteins; WSN-(water)-soluble nitrogen at $\mathrm{pH} 4.6$; $\mathrm{TN}$-total nitrogen; $\beta$-LG—native $\beta$-lactoglobulin; $\alpha$-LA-native $\alpha$-lactalbumin; $\mathrm{CMP}$ - caseinomacropeptide.

\begin{tabular}{|c|c|c|c|c|c|c|c|}
\hline \multirow[t]{2}{*}{ Cream } & \multicolumn{3}{|c|}{ Kjeldahl Analysis } & \multicolumn{4}{|c|}{ RP-HPLC Profile } \\
\hline & \%INSP & $\% \mathrm{SP}^{2}$ & WSN/TN & $\beta-\mathrm{LG}, \mathrm{mg} / \mathrm{L}$ & $\alpha-\mathrm{LA}, \mathrm{mg} / \mathrm{L}$ & $\mathrm{CMP}, \mathrm{mg} / \mathrm{L}$ & $\beta$-LG/ $\alpha$-LA \\
\hline \multicolumn{8}{|c|}{ Origin $(n=12)$} \\
\hline BSM & $3.74 \mathrm{c}$ & $1.37 \mathrm{~b}$ & $26.75 \mathrm{a}$ & $6407 \mathrm{~b}$ & $2220 \mathrm{~b}$ & & $2.92 \mathrm{~b}$ \\
\hline $\mathrm{BCM}$ & $2.08 \mathrm{~b}$ & $1.0 \mathrm{a}$ & $32.46 \mathrm{~b}$ & 3057 a & $1401 \mathrm{a}$ & & $2.19 \mathrm{a}$ \\
\hline BSW & $0.29 \mathrm{a}$ & $1.65 c$ & $85.36 \mathrm{c}$ & $6747 c$ & $2179 \mathrm{~b}$ & 2348 & $3.12 \mathrm{~b}$ \\
\hline se & 0.04 & 0.03 & 1.27 & 84.7 & 49.7 & & 0.09 \\
\hline \multicolumn{8}{|c|}{ Heat treatment $(n=18)$} \\
\hline $\mathrm{T}$ & $1.96 \mathrm{a}$ & $1.39 \mathrm{~b}$ & $51.03 \mathrm{~b}$ & $5582 \mathrm{~b}$ & 1984 & $2378^{1}$ & 2.75 \\
\hline $\mathrm{P}$ & $2.12 \mathrm{~b}$ & $1.29 \mathrm{a}$ & $45.35 \mathrm{a}$ & $5227 \mathrm{a}$ & 1882 & $2318^{1}$ & 2.73 \\
\hline se & 0.03 & 0.03 & 1.04 & 69.2 & 40.46 & 65.7 & 0.07 \\
\hline \multicolumn{8}{|c|}{ Storage $(n=18)$} \\
\hline NF & 2.14 & $1.29 \mathrm{a}$ & $45.07 \mathrm{a}$ & 5273 & 1883 & $2575^{1} \mathrm{~b}$ & 2.74 \\
\hline $\mathrm{F}$ & 1.94 & $1.39 \mathrm{~b}$ & $51.31 \mathrm{~b}$ & 5536 & 1984 & $2122^{1} \mathrm{a}$ & 2.69 \\
\hline se & 0.03 & 0.03 & 1.035 & 69.2 & 40.46 & 65.7 & 0.07 \\
\hline
\end{tabular}

${ }^{1} n=6 ;{ }^{2}$ WSN $\times 6.38$; a-c-statistically significant differences (LSD, $\left.p<0.05\right)$ within the means of each experimental factor. 


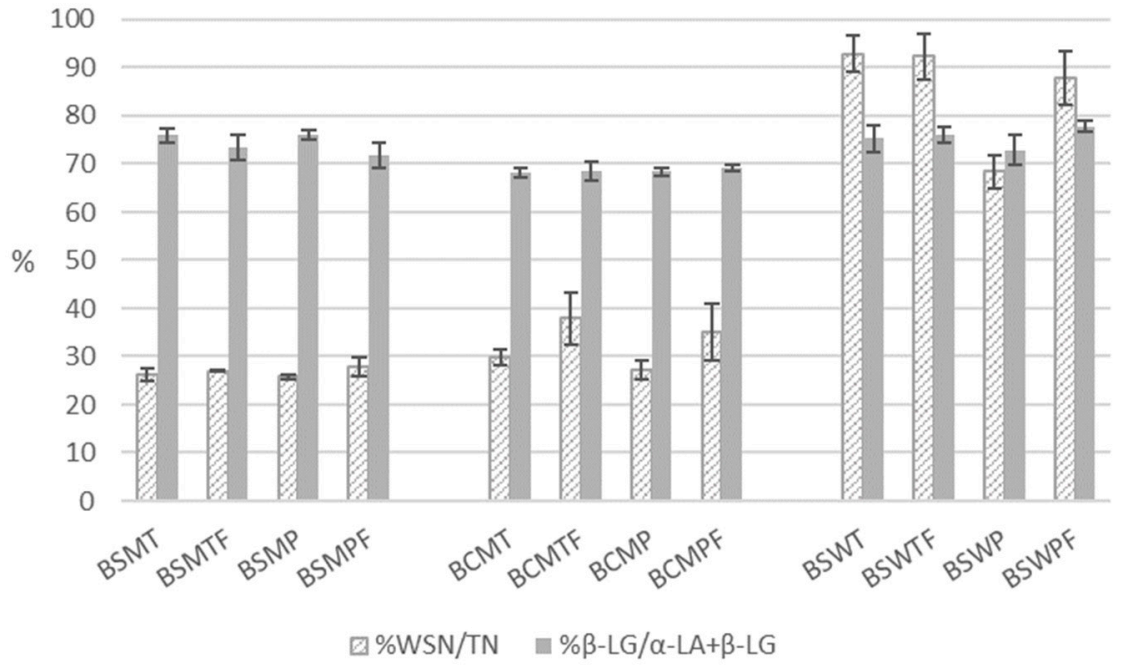

Figure 2. Soluble nitrogenous fraction of various types of buttermilk. WSN-nitrogen soluble at $\mathrm{pH}$ 4.6; TN-total nitrogen; $\beta$-LG- $\beta$-lactoglobulin; $\alpha$-LA- $\alpha$-lactalbumin; BSMT-buttermilk from SM-thermized cream; BCMT—buttermilk from CM-thermized cream; BSWT-buttermilk from SW-thermized cream; BSMP_-buttermilk from SM-pasteurized cream; BCMP-buttermilk from CM-pasteurized cream; BSWP-buttermilk from SW-pasteurized cream. T-cream thermized at $68^{\circ} \mathrm{C}$ for $10 \mathrm{~min} ; \mathrm{P}$-cream pasteurized at $68^{\circ} \mathrm{C}$ for $30 \mathrm{~min}$. $\mathrm{F}$ at the end of a buttermilk code indicates the use of frozen cream.

The churning of frozen cream significantly increased $(p<0.05)$ the nitrogen content of the fraction soluble at $\mathrm{pH} 4.6$ symbolized earlier as WSN and consequently the ratio WSN/TN. Possible explanations could be proteolysis due to additional treatments of cream before churning and changes in the colloidal phase induced by freezing. According to multifactor ANOVA, the pasteurization of cream did not affect the total protein and protein on dry matter contents of buttermilk but significantly decreased $(p<0.05)$ the concentration of WSN. The latter can result from the heat induced denaturation of whey proteins with the exception of $\alpha$-lactalbumin ( $\alpha$-LA), which tolerates the pasteurization conditions applied in the present study [41]. In fact, the statistically significant effect of heat treatment was due to BSW. Heating conditions did not significantly affect the soluble fraction of sweet sheep or cow cream buttermilks. The mean WSN/TN ratios $(n=6)$ of BSMT and BSMP were $26.6 \pm 0.95$ and $26.9 \pm 1.75 \%$, respectively. The respective percentages for BCMT and BCMP were $33.9 \pm 5.7$ and $31 \pm 5.81 \%$. A statistically significant difference $(p<0.05)$ was observed in the WSN/TN ratios of whey-originated BSWT and BSWP, which were $92.6 \pm 3.88$ and $78.1 \pm 11.355$, respectively. The reduction in soluble nitrogen observed in BSWP can be partially assigned to the - not statistically significant-reduction in native $\beta$-lactoglobulin ( $\beta-L G)$, which was $8 \%$ lower compared with its thermized counterpart. Under heating conditions similar to the pasteurization conditions of the present study $\left(68^{\circ} \mathrm{C}\right.$ for $30 \mathrm{~min}$ )-which do not coincide with the denaturation of $\beta$-LG- $\beta$-LG is associated with MFGM proteins via disulphide bonds $[53,54]$. Most of the original MFGM proteins were involved in interactions with either serum proteins or other MFGM proteins during heating at $65{ }^{\circ} \mathrm{C}$ for $30 \mathrm{~min}$ [53]. Under the same conditions, approximately $0.3 \mathrm{mg}$ of $\beta$-LG per $g$ fat are associated with MFGM, 3 times that estimated for unheated milk [54].

Variable quantities of soluble nitrogen in sweet buttermilk of cow origin have been estimated in various studies. The variability is mainly due to different heat treatments of cream. O' Connel and Fox [55] estimated the ratio $\mathrm{pH} 4.6$ soluble protein to total protein as $25 \pm 3.2 \%$ and $24.4 \pm 1$ for skimmed buttermilk from raw cream and skimmed raw milk, respectively. Ratios of soluble nitrogen to TN of various sweet cream and whey buttermilk powders lower than the findings of the present study, have been presented by Sodini et al. [2]. They report $14.5-21.6 \%$ and $60 \% \mathrm{pH} 4.6$-soluble nitrogen on TN for cream and whey buttermilk, respectively. The respective ratios for non-protein nitrogen were 
6.3-7.6 and 27.1\%. In the publication of Gassi et al. [5], the $\mathrm{pH} 4.6$-soluble nitrogen on $\mathrm{TN}$ of sweet buttermilk from cream heated at $88-94{ }^{\circ} \mathrm{C}$ for $80 \mathrm{~s}$ ranged from 36.5 to $32.6 \%$ and the non-protein nitrogen was $26.1-28.3 \%$ of TN. The concentration of $\beta$-LG was from 1600 to $290 \mathrm{mg} / \mathrm{kg}$ and that of $\alpha$-LA from 650 to $330 \mathrm{mg} / \mathrm{kg}$, depending on cream heat treatment-much lower than our findings.

As expected, the insoluble protein fraction at $\mathrm{pH} 4.6$ (INSP) was very low in BSW (Table 3) since cream originated from cheese whey normally contains traces of caseins that have not been retained in the cheese curd. However, INSP in buttermilk does not consist entirely of caseins. Some of the MFGM proteins, such as butyrophilin and xanthine oxidase, along with denatured whey proteins precipitate under acidic conditions [2,55,56]. Caseinomacropeptide (CMP), which is one of the products of rennet-induced clotting, contributed substantially to the soluble fraction of this type of buttermilk in the present study (BSW, Table 3).

\subsection{Biofunctional Potential}

\subsubsection{Minerals}

The heat treatment of cream did not affect the concentration of major minerals of buttermilks. The effect of cream preservation was statistically significant $(p<0.05)$ only for the phosphorus content of BSW (Table 4). On the contrary, there was a strong influence of the cream origin on the concentration of major minerals in buttermilks.

Table 4. Major minerals (mg/100 g buttermilk) of various types of buttermilk. Mean and standard deviation (sd) of 6 experiments. BSM-buttermilk from sheep milk cream; BCM-buttermilk from cow milk cream; BSW-buttermilk from sheep cheese whey cream; F at the end of a buttermilk code indicates the use of frozen cream.

\begin{tabular}{|c|c|c|c|c|c|c|c|c|c|c|}
\hline Cream & $\mathrm{Ca}$ & & Mg & & $\mathbf{K}$ & & $\mathrm{Na}$ & & $\mathbf{P}$ & \\
\hline & Mean & sd & Mean & sd & Mean & sd & Mean & sd & Mean & sd \\
\hline \multicolumn{11}{|c|}{ Non-frozen } \\
\hline BSM & $113.28 \mathrm{c}$ & 4.66 & $20.55 \mathrm{~b}$ & 0.71 & $112.45 \mathrm{a}$ & 5.19 & $76.63 \mathrm{a}$ & 4.52 & $120.28 \mathrm{c}$ & 4.07 \\
\hline BCM & $57.03 \mathrm{~b}$ & 3.22 & $13.73 \mathrm{a}$ & 0.87 & 149.25 c & 14.40 & $75.23 \mathrm{a}$ & 7.45 & 79.77 b & 3.76 \\
\hline BSW & $22.42 \mathrm{a}$ & 1.37 & $13.48 \mathrm{a}$ & 0.82 & $130.43 \mathrm{~b}$ & 9.94 & $91.77 \mathrm{~b}$ & 5.05 & $46.7 \mathrm{a}$ & 3.18 \\
\hline \multicolumn{11}{|l|}{ Frozen } \\
\hline BSMF & $109.48 \mathrm{c}$ & 4.33 & $20.93 \mathrm{~b}$ & 1.14 & $125.73 \mathrm{a}$ & 5.35 & $77.25 \mathrm{a}$ & 7.24 & $117.77 \mathrm{c}$ & 7.43 \\
\hline BCMF & $52.72 \mathrm{~b}$ & 5.45 & $12.92 \mathrm{a}$ & 0.71 & $146.85 \mathrm{~b}$ & 7.96 & $81.35 a, b$ & 5.32 & $76.07 \mathrm{~b}$ & 2.72 \\
\hline BSWF & $23.7 \mathrm{a}$ & 2.35 & $13.95 \mathrm{a}$ & 0.76 & $119.3 \mathrm{a}$ & 9.34 & $86.85 \mathrm{~b}$ & 7.94 & $40.6 a^{*}$ & 2.92 \\
\hline
\end{tabular}

a-c-statistically significant differences (LSD, $p<0.05$ ) within the groups of non-frozen or frozen cream; *-significant difference (LSD, $p<0.05$ ) between buttermilks of the same type from non-frozen or frozen cream.

It is well known that the mineral content and profile of milk is correlated with the protein content and is related to milk origin. Sodium, potassium and chloride are diffusible and two thirds of calcium, one third of magnesium and about half the phosphate are associated with casein micelle. Therefore, it can be expected that the decrease in INSP could decrease major minerals, such as calcium and phosphorus. Potassium and sodium contents that are not associated with casein are in accordance with literature for milk, e.g., up to 140 and $150 \mathrm{mg}$ potassium per $100 \mathrm{~mL}$ milk are reported for SM and CM, respectively [35]. Since they are diffusible, they are transferred to the whey, as confirmed in Table 4 . The opposite holds true for calcium and phosphorus that are retained in the cheese curd along with paracasein. The phosphorus concentrations in SM and CM are 124-158 and 92-99 mg per $100 \mathrm{~mL}$, respectively. The lower contribution of INSP to the BCM compared with milk can explain the reduced phosphorus and calcium content of the former, as in Table 4 .

Calcium content of buttermilks was low (Table 4) considering that SM and CM contain 195-200 and 104-128 mg calcium per $100 \mathrm{~mL}$ [35]. Moreover, the calcium to phosphorus ratios in BSM and BCM, both released from the churning of sweet cream, were 0.94 and 
0.70 , i.e., much lower than the average 1.30 observed in milk. Therefore, the churning selectively reduced calcium.

Low concentration of calcium in buttermilk has been previously presented. Ramachandra Rao et al. [57] estimated 20-22 mM calcium (approx. $80-88 \mathrm{mg} / 100 \mathrm{~mL}$ ) in buttermilk that is lower than the 26-32 mM calcium in milk [1]. O'Connell and Fox [55] found lower calcium content in skimmed buttermilk compared with skimmed milk, i.e., $94.8 \pm 5.4$ and $119.5 \pm 9.3 \mathrm{mg}$ per $100 \mathrm{~g}$, respectively. They suggested as a possible explanation the formation of insoluble salts due to complexation of calcium with free fatty acids released into the aqueous phase during the breaking of the oil-in-water emulsion. On the other hand, Gassi et al. [5] reported higher calcium concentration in buttermilks, ranging from 97 to $115 \mathrm{mg} / 100 \mathrm{~g}$. Nevertheless, the calcium and phosphorus contents were correlated with the INSP, in which casein is included, i.e., $r=0.97$ and $r=0.99$, respectively.

\subsubsection{Antioxidant Activity}

The antioxidant potential of various types of buttermilks, by means of two assays, is presented in Table 5. The heat treatment of cream did not affect the results.

Table 5. Antioxidant potential of various types of buttermilk. Mean and standard deviation (sd) of six experiments. BSM-buttermilk from sheep milk cream; BCM-buttermilk from cow milk cream; BSW-buttermilk from sheep cheese whey cream; F at the end of a buttermilk code indicates the use of frozen cream.

\begin{tabular}{llclc}
\hline Cream & \%DPPH· Radical Scavenging Activity (RSA) & \multicolumn{2}{l}{ \%Fe $^{2+}$ Chelating Activity (CA) } \\
\hline & Mean & sd & Mean & sd \\
\hline Non-frozen & & & & \\
BSM & $79.04 \mathrm{~b}$ & 2.79 & $84.14 \mathrm{c}$ & 2.92 \\
BCM & $62.95 \mathrm{a}$ & 2.64 & $74.69 \mathrm{~b}$ & 6.42 \\
BSW & $81.10 \mathrm{~b}$ & 4.30 & $17.80 \mathrm{a}$ & 4.43 \\
Frozen & & & & \\
BSMF & $73.90 \mathrm{c}$ & 5.20 & $90.53 \mathrm{c}^{*}$ & 1.01 \\
BCMF & $60.56 \mathrm{a}$ & 3.50 & $66.54 \mathrm{~b}^{*}$ & 1.76 \\
BSWF & $67.115 \mathrm{~b}^{*}$ & 3.13 & $17.36 \mathrm{a}$ & 8.68 \\
\hline
\end{tabular}

a-c-statistically significant differences (LSD, $p<0.05$ ) within the groups of non-frozen or frozen cream; *-significant difference (LSD, $p<0.05)$ between buttermilks of the same type from non-frozen or frozen cream.

The \%DPPH $\cdot$ RSA was significantly $(p<0.05)$ higher in BSM and BSW compared with BCM. The \%DPPH. RSA was positively and significantly correlated with the contents of soluble proteins $(0.52, p=0.0011)$ and native whey proteins in buttermilk (CMP, 0.72 , $p=0.009 ; \alpha-\mathrm{LA}, 0.62, p=0.0001 ; \beta-\mathrm{LG}, 0.64, p=0.0001)$. The concentration of whey proteins was significantly higher $(p<0.05)$ in BSM and BSW than in BCM (Table 3). Considering the above and that there was no significant correlation $(p>0.05)$ between \%DPPH. RSA and INSP, we suggest that DPPH. RSA should be attributed mainly to whey proteins and other $\mathrm{pH}$ 4.6-soluble nitrogenous compounds. Previously, Conway et al. [46] have associated radical absorbance capacity with peptides derived from whey proteins, mainly $\alpha$-LA and $\beta$-LG; meanwhile, according to Cichosz et al. [58], all $\beta$-LG-derived peptides possess RSA. Khan et al. [59] have attributed RSA of whey proteins to amino acids that contain sulphur compounds, whereas Cichosz et al. [58] have marked the significance of peptide secondary structure. Moreover, RSA has been also associated with MFGM proteins by Conway et al. [46], who suggested butyrophilin as the main source of peptides with potent antioxidant effect. Furthermore, the PL fraction of MFGM is considered responsible for antioxidant activity, as they contain poly-unsaturated fatty acids capable of binding cations and ether lipids, which act very effectively against hydroxyl radicals [58].

Both the cream origin and preservation affected significantly $(p<0.05)$ the $\% \mathrm{Fe}^{2+} \mathrm{CA}$. The highest $\% \mathrm{Fe}^{2+} \mathrm{CA}$ was detected in BSM and the lowest in BSW, which exhibited 5-fold lower values compared with the former. Since cheese whey mainly contains whey proteins and no or traces of caseins, the $\mathrm{Fe}^{2+} \mathrm{CA}$ could be assigned mainly to casein and the peptides derived from it. In the present study, $\% \mathrm{Fe}^{2+} \mathrm{CA}$ correlated positively and strongly $(0.95$, 
$p=0.000)$ with \%INSP - that is, mostly caseins-and negatively and significantly with $\%$ WSN $(-0.60, p=0.0001)$. Conway et al. [46] have attributed $\mathrm{Fe}^{2+} \mathrm{CA}$ to casein-derived peptides and especially phosphopeptides, which can interact with metals due to the polar side chains of some amino acid parts. This complies with the strong positive correlation $(p=0.0000)$ of $\% \mathrm{Fe}^{2+} \mathrm{CA}$ with $\%$ phosphorus $(0.92)$ and $\%$ calcium $(0.88)$ in our study, while $\%$ INSP was also strongly positively correlated $(p=0.0000)$ with both calcium $(0.97)$ and phosphorus (0.99) contents. A considerable CA for casein, casein fragments and phosphopeptides has been also reported [58,59]. Moreover, $\% \mathrm{Fe}^{2+} \mathrm{CA}$ was higher in BSM compared with its cow counterpart apparently due to its higher casein content.

\subsubsection{Phospholipids (PL)}

The PL content of the buttermilks expressed in g per $100 \mathrm{~g}$ buttermilk and in $\mathrm{g}$ per $100 \mathrm{~g}$ fat are presented in Figure 3. For comparison reasons, the fat contents of buttermilks are also shown. Both expressions of PL concentration were not affected by the experimental factors. The average PL content of BSM, BCM and BSW was $0.037 \pm 0.01,0.037 \pm 0.024$ and $0.026 \pm 0.012 \mathrm{~g}$ per $100 \mathrm{~g}$ buttermilk, and $1.65 \pm 0.39,1.92 \pm 0.54$ and $2.02 \pm 0.87 \mathrm{~g}$ per $100 \mathrm{~g}$ fat, respectively. The respective contents expressed on buttermilk total solids were $0.269 \pm 0.066,0.313 \pm 0.171$ and $0.28 \pm 0.13 \mathrm{~g}$ per $100 \mathrm{~g}$ total solids.

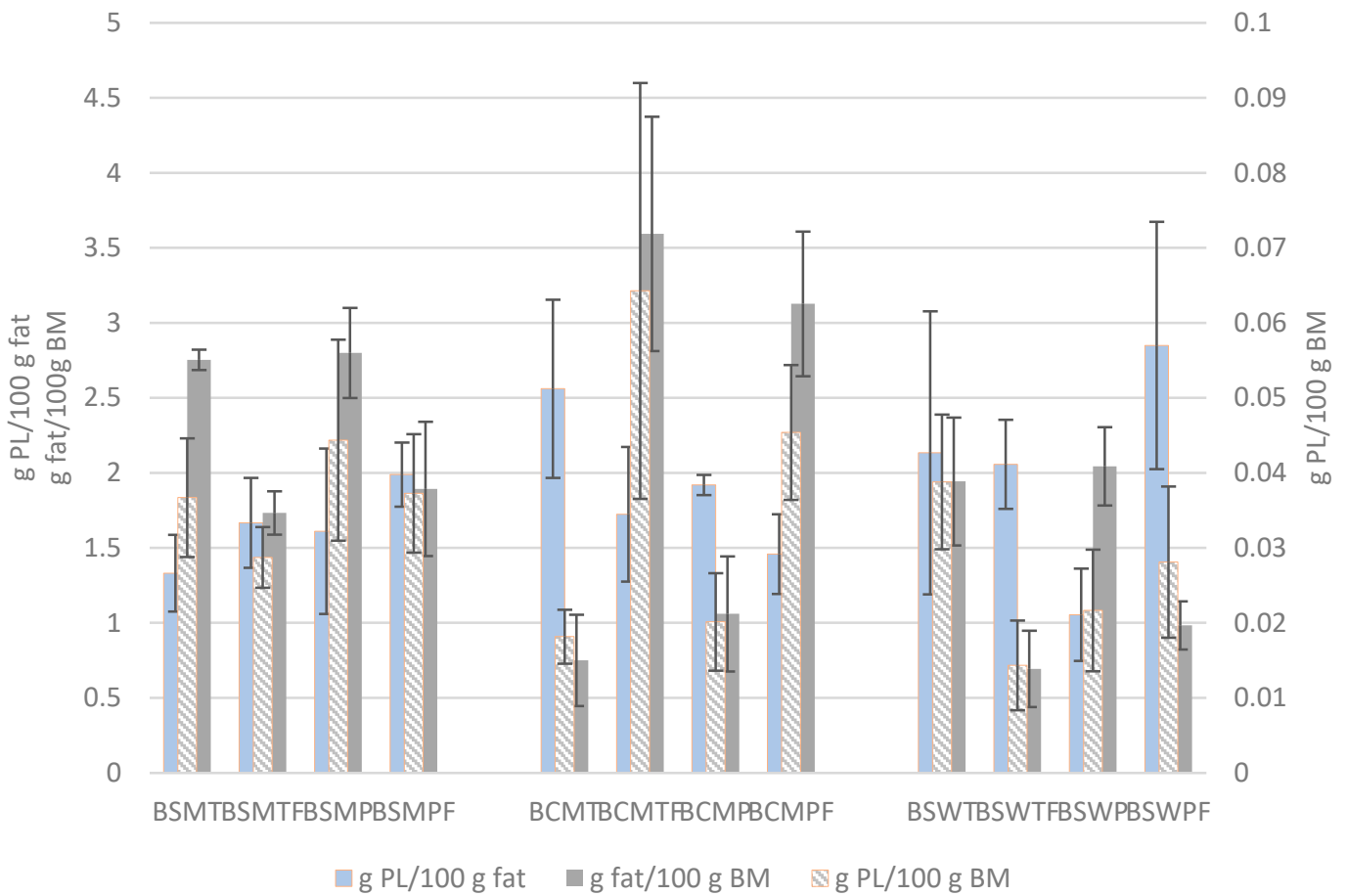

Figure 3. Phospholipid (PL) concentration and fat content of various types of buttermilk. Mean and standard deviation of three experiments. BSMT-buttermilk from SM-thermized cream; BCMTbuttermilk from CM-thermized cream; BSWT-buttermilk from SW-thermized cream; BSMPbuttermilk from SM-pasteurized cream; BCMP_-buttermilk from CM-pasteurized cream; BSWPbuttermilk from SW-pasteurized cream. T-cream thermized at $68^{\circ} \mathrm{C}$ for $10 \mathrm{~min}$; $\mathrm{P}$-cream pasteurized at $68{ }^{\circ} \mathrm{C}$ for $30 \mathrm{~min}$. $\mathrm{F}$ at the end of a buttermilk code indicates the use of frozen cream.

Variable PL concentrations in buttermilk influenced by the manufacturing conditions and expressed in different ways are presented in the literature. Several publications report higher total PL concentrations in untreated buttermilk than our findings, such as $2.1 \mathrm{~g}$ per $100 \mathrm{~g}$ buttermilk dry matter [49], 0.14 and $0.10 \mathrm{~g}$ per $100 \mathrm{~g}$ regular and whey buttermilk [30], $0.16 \mathrm{~g}$ per $100 \mathrm{~g}$ buttermilk or $2.03 \mathrm{~g}$ per $100 \mathrm{~g}$ buttermilk dry matter [60], 1.27-1.34 or $1.87 \mathrm{~g}$ per $100 \mathrm{~g}$ regular and whey buttermilk dry matter [2], 0.082-0.112 g per $100 \mathrm{~g}$ buttermilk from differently heat-treated creams [5], and $0.99 \mathrm{~g}$ per $100 \mathrm{~g}$ buttermilk [50]. 
Similarly to our results, Verardo et al. [61] estimated a concentration of 0.024-0.044 g per $100 \mathrm{~g}$ buttermilk, depending on butter making conditions, and Konrad et al. [62] reported 0.03-0.053 g per $100 \mathrm{~g}$ whey buttermilk depending on the fat content of whey cream.

Barry et al. [50] showed that different extraction methods result in statistically significantly different PL contents in milk. Morin et al. [26] expressed concern about the interference of complexes among milk proteins, MFGM fractions and PL in the extraction of PL. The association between casein and MFGM in buttermilk is a well-known phenomenon that limits the yield of MFGM-enriched fractions from buttermilk. The addition of sodium citrate before the microfiltration of milk [63], casein precipitation by acid and rennet coagulation [64], or enzymatic hydrolysis of buttermilk proteins before ultrafiltration and diafiltration [62,65] — that can be followed by supercritical extraction using carbon dioxide alone or with ethanol $[52,66,67]$ - have been applied to address this difficulty. In this respect, Spitsberg et al. [68] proved that casein and MFGM in buttermilk are associated via calcium bridges between phosphorylated casein and phosphate of PL. They used calcium-binding salts to dissociate these complexes into their components and to improve substantially the recovery of MFGM from buttermilk. Moreover, a considerable amount of PL has been considered to migrate to the cheese water soluble extract [69] despite the fact that the methods for their estimation are based on lipid extraction.

\subsection{Particle Size Distribution}

The distribution of particle size in various types of buttermilk are shown in Figure 4. Particles with diameter $>1 \mu \mathrm{m}$ and maximum at 2.5-2.8 $\mu \mathrm{m}$ predominated in BSM and BSW, both of sheep origin. Nanoparticles with diameter $0.2-0.5 \mu \mathrm{m}$ that can be assigned to casein micelles were also observed. Pasteurization increased the volume of particles with diameter $>15 \mu \mathrm{m}$. On the other hand, particles in BCM with diameters greater than $10 \mu \mathrm{m}$, with maximum at 35-38 $\mu \mathrm{m}$ indicate the existence of aggregates or structures. Up to a point this difference can be assigned to the greater size of cow MFG compared with its sheep counterpart $[34,35]$.

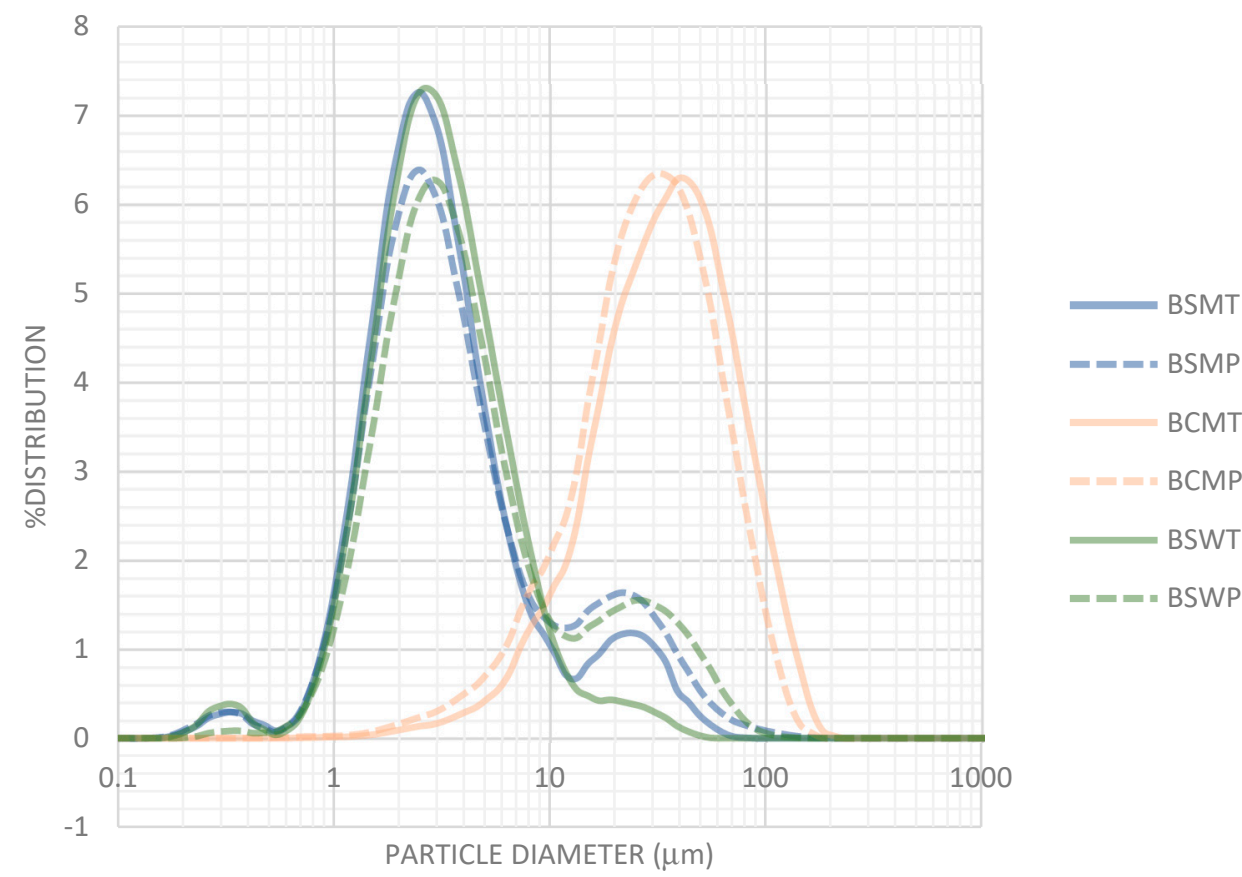

Figure 4. Particle size distribution in buttermilks. Mean percentages of three experiments. BSMTbuttermilk from SM-thermized cream; BCMT-buttermilk from CM-thermized cream; BSWTbuttermilk from SW-thermized cream; BSMP_-buttermilk from SM-pasteurized cream; BCMPbuttermilk from CM-pasteurized cream; BSWP-buttermilk from SW-pasteurized cream. T-cream thermized at $68^{\circ} \mathrm{C}$ for $10 \mathrm{~min}$; $\mathrm{P}$ - cream pasteurized at $68^{\circ} \mathrm{C}$ for $30 \mathrm{~min}$. 
Relevant literature information is for buttermilk of cow origin. Morin et al. [26] report the existence of MFGM fragments with a size ranging from 0.1 to 2-3 $\mu \mathrm{m}$ and of structures consisted of caseins trapped in folded MFGM fragments. Particles with a diameter greater than $10 \mu \mathrm{m}$ have been observed by Lambert et al. [51] in industrial whole buttermilk in very variable quantities, e.g., $6 \pm 21 \%$ of total particles. These particles were large MFG resulted from the coalescence of small globules, aggregated MFG-i.e., butter fines-or flexible and folded fragments of MFGM.

\subsection{Functional Properties}

All three experimental factors had a statistically significant effect on the viscosity (mPa.s) of buttermilks, presented in Table 6 and Figure 5. The substantially higher viscosity values of BCM are in accordance with the presence of large particles in the profile of Figure 4. Moreover, at $\mathrm{pH} 6.6$ that is close to typical $\mathrm{pH}$ of sweet buttermilk, the more intense heat treatment significantly increased $(p<0.05)$ the viscosity of BCM and BSW opposite to BSM, which had the highest INSP content. Apparently, heat-induced complexation of serum proteins on the surface of the casein micelles of BSM did not significantly affect their size. The high concentration of casein of BSM indicates an abundance of potent complexation sites (Table 3, Figure 2). At pH 4.6, the viscosity of both sweet cream buttermilks was substantially increased due to the formation of casein aggregates. The increase was not significant $(p>0.05)$ for BSW due to low casein concentration.

Table 6. Viscosity (mPa.s) of various types of buttermilk at different $\mathrm{pH}$. Mean and standard deviation (sd) of three experiments. BSM-buttermilk from sheep milk cream; BCM-buttermilk from cow milk cream; BSW-buttermilk from sheep cheese whey cream; $\mathrm{T}$-cream thermized at $68{ }^{\circ} \mathrm{C}$ for $10 \mathrm{~min}$; $\mathrm{P}$-cream pasteurized at $68^{\circ} \mathrm{C}$ for $30 \mathrm{~min}$; $\mathrm{F}$ at the end of a buttermilk code indicates the use of frozen cream.

\begin{tabular}{|c|c|c|c|c|c|c|c|c|}
\hline \multirow[t]{3}{*}{ Cream } & \multicolumn{4}{|c|}{ Viscosity (mPa.s) pH 6.6} & \multicolumn{4}{|c|}{ Viscosity (mPa.s) pH 4.5} \\
\hline & \multicolumn{2}{|c|}{ Thermized $(\mathrm{T})$} & \multicolumn{2}{|c|}{ Pasteurized (P) } & \multicolumn{2}{|c|}{ Thermized $(T)$} & \multicolumn{2}{|c|}{ Pasteurized (P) } \\
\hline & Mean & sd & Mean & sd & Mean & sd & Mean & sd \\
\hline \multicolumn{9}{|c|}{ Non-frozen } \\
\hline BSM & $3.21 \mathrm{a}$ & 0.132 & $3.43 \mathrm{a}$ & 0.24 & $8.28 \mathrm{~b}$ & 0.46 & 5.48 a \# & 0.38 \\
\hline $\mathrm{BCM}$ & $8.33 \mathrm{~b}$ & 0.487 & $16.79 \mathrm{~b} \#$ & 1.22 & $11.46 \mathrm{c}$ & 0.71 & $27.91 \mathrm{~b} \#$ & 1.67 \\
\hline BSW & $2.58 \mathrm{a}$ & 0.044 & $3.89 \mathrm{~b} \#$ & 0.16 & $3.42 \mathrm{a}$ & 0.31 & $3.86 \mathrm{a}$ & 0.37 \\
\hline \multicolumn{9}{|l|}{ Frozen } \\
\hline BSMF & $3.21 \mathrm{a}$ & 0.3 & $2.16 \mathrm{a}$ & 0.15 & $8.68 b$ * & 0.28 & $8.34 \mathrm{~b}$ & 0.17 \\
\hline $\mathrm{BCMF}$ & $14.99 \mathrm{~b} *$ & 1.27 & $17.68 \mathrm{~b} \#$ & 0.90 & $24.80 c^{*}$ & 2.35 & 30.41 c \# & 2.36 \\
\hline BSWF & $3.61 \mathrm{a} *$ & 0.142 & $4.37 \mathrm{c} \#$ * & 0.48 & $3.38 \mathrm{a}$ & 0.28 & $3.75 \mathrm{a}$ & 0.36 \\
\hline
\end{tabular}

a-c-statistically significant differences (LSD, $p<0.05$ ) within the groups of non-frozen or frozen cream *-significant difference (LSD, $p<0.05$ ) between buttermilks of the same type from non-frozen or frozen cream; $\#$ - significant difference (LSD, $p<0.05$ ) between buttermilks of the same type from thermized or pasteurized cream.

The remaining physicochemical properties of buttermilks are shown in Table 7, grouped by the origin and storage of cream. According to multifactor ANOVA, the heat treatment of cream did not affect statistically significantly the physicochemical properties of buttermilks. The churning of frozen cream significantly decreased $(p<0.05)$ the FA at $\mathrm{pH} 6.6$ and $\mathrm{pH} 4.5$ and the PS at $\mathrm{pH}$ 6.6.

Regarding PS, as seen from Table 7, it varied from $\sim 23$ to 92\%. For both ways of cream preservation, BCM with a $\mathrm{pH}$ of 6.6 exhibited high PS values, i.e., 90 and $92 \%$, for non-frozen and frozen creams, respectively. BSM from non-frozen sweet cream also presented high PS value (92\%). For BSM and BCM, both non-frozen and frozen, PS decreased significantly, e.g., from $\sim 92$ to $\sim 23 \%$ for the BCMF, as the $\mathrm{pH}$ was lowered to 4.5 , showing a great $\mathrm{pH}$ dependence. PS of BSW, for both pHs, was in the area of $59-67 \%$, suggesting that the $\mathrm{pH}$ was not as important as for the rest of the samples. 

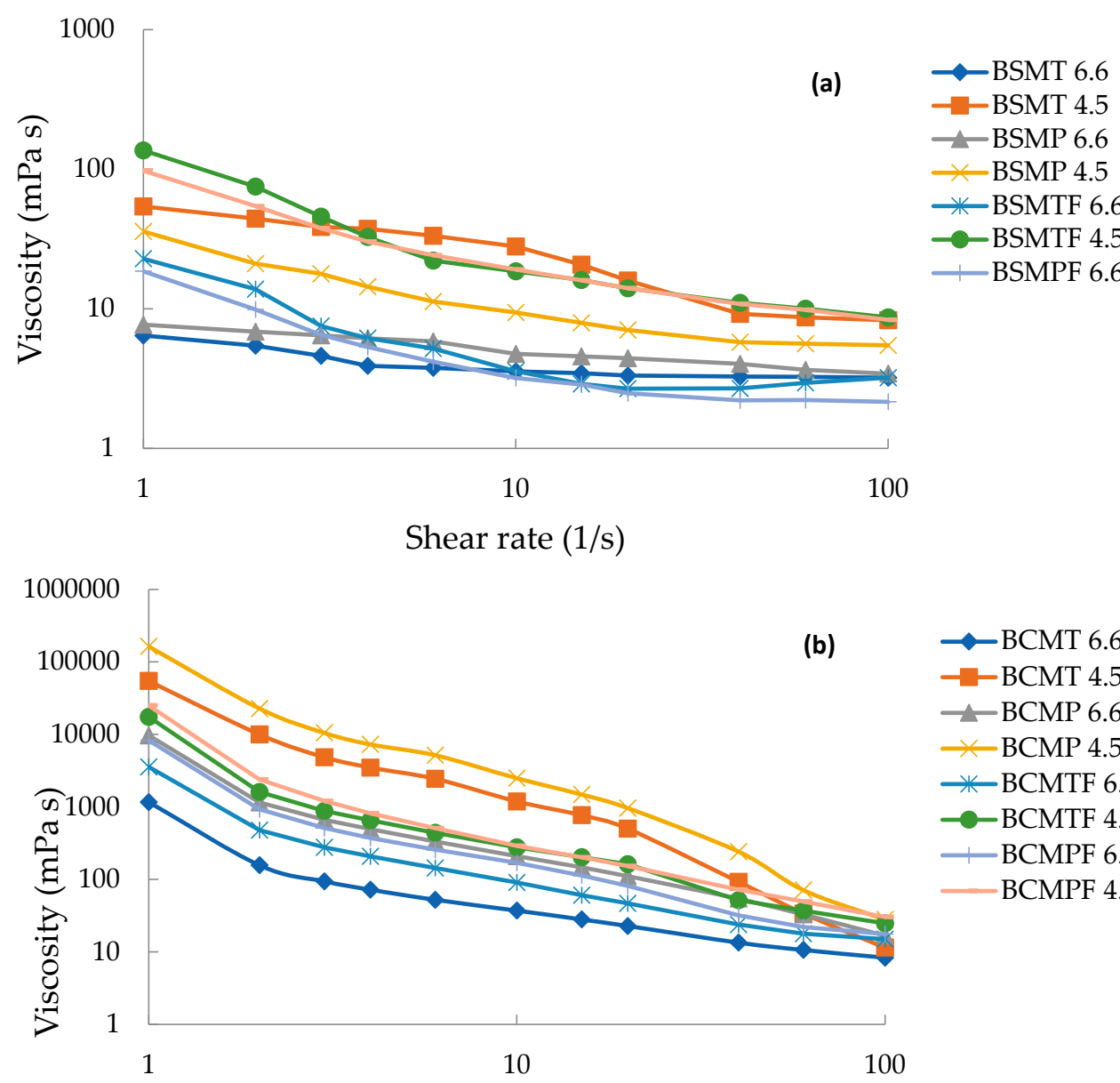

$\smile$ BCMT 6.6

-BCMT 4.5

$\rightarrow$ BCMP 6.6

$\sim$ BCMP 4.5

* BCMTF 6.6

-BCMTF 4.5

- BCMPF 6.6

- BCMPF 4.5

Shear rate $(1 / \mathrm{s})$
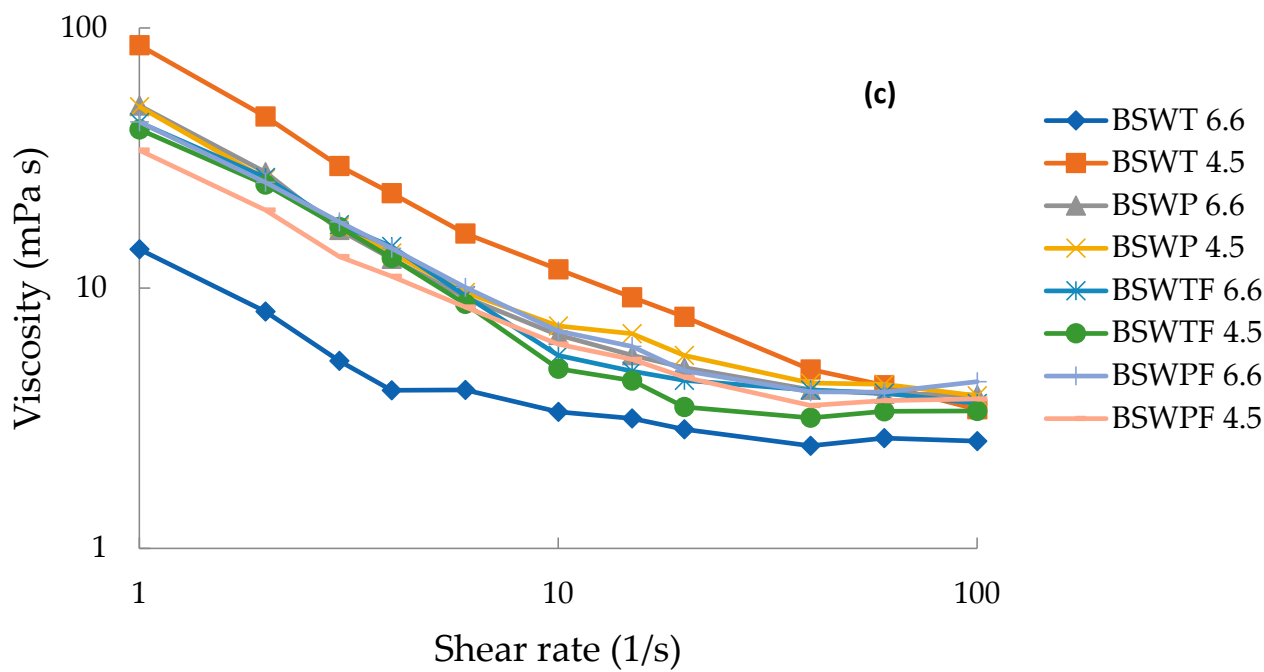

Figure 5. Viscosity ( $\mathrm{mPa} \cdot \mathrm{s})$ of buttermilk from sweet sheep cream (a), sweet cow cream (b) and sheep whey cream (c) at different pH. BSMT—buttermilk from SM-thermized cream; BCMT_buttermilk from CM-thermized cream; BSWT-buttermilk from SW-thermized cream; BSMP_-buttermilk from SM-pasteurized cream; BCMP_-buttermilk from CM-pasteurized cream; BSWP-buttermilk from SW-pasteurized cream. T-cream thermized at $68^{\circ} \mathrm{C}$ for $10 \mathrm{~min}$; $\mathrm{P}$, cream pasteurized at $68^{\circ} \mathrm{C}$ for $30 \mathrm{~min}$. $\mathrm{F}$ at the end of a buttermilk code indicates the use of frozen cream. 
Table 7. Physicochemical properties of various types of buttermilk. Mean and standard deviation (sd) of six experiments. BSM-buttermilk from sheep milk cream; BCM-buttermilk from cow milk cream; BSW-buttermilk from sheep cheese whey cream; F at the end of a buttermilk code indicates the use of frozen cream.

\begin{tabular}{|c|c|c|c|c|c|c|c|c|c|c|c|c|}
\hline \multirow{3}{*}{ Cream } & \multicolumn{4}{|c|}{ \%Emulsion Stability (ES) } & \multicolumn{4}{|c|}{ Foaming Ability (FA) } & \multicolumn{4}{|c|}{ \%Protein Solubility (PS) } \\
\hline & \multicolumn{2}{|l|}{ pH 6.6} & \multicolumn{2}{|l|}{ pH 4.5} & \multicolumn{2}{|l|}{ pH 6.6} & \multicolumn{2}{|l|}{ pH 4.5} & \multicolumn{2}{|l|}{ pH 6.6} & \multicolumn{2}{|l|}{ pH 4.5} \\
\hline & Mean & sd & Mean & sd & Mean & sd & Mean & sd & Mean & sd & Mean & sd \\
\hline Non-frozen & & & & & & & & & & & & \\
\hline BSM & $20.67 \mathrm{~b}$ & 2.90 & 56.09 & 7.87 & $0.235 \mathrm{a}$ & 0.044 & 0.242 & 0.018 & $92.08 \mathrm{~b}$ & 7.48 & $26.10 \mathrm{a}$ & 3.11 \\
\hline $\mathrm{BCM}$ & $15.86 \mathrm{a}$ & 0.81 & 50.64 & 9.06 & $0.235 \mathrm{a}$ & 0.049 & 0.315 & 0.223 & $89.8 \mathrm{~b}$ & 4.64 & $25.42 \mathrm{a}$ & 1.29 \\
\hline BSW & $19.55 b$ & 1.45 & 49.44 & 2.32 & $0.327 \mathrm{~b}$ & 0.079 & 0.375 & 0.074 & $66.8 \mathrm{a}$ & 2.26 & $67.04 \mathrm{~b}$ & 6.37 \\
\hline Frozen & & & & & & & & & & & & \\
\hline BSMF & 19.21 & 1.85 & $54.76 \mathrm{~b}$ & 2.74 & $0.182 \mathrm{~b}$ & 0.070 & $0.352 c^{*}$ & 0.098 & 79.94 b * & 8.46 & $34.01 \mathrm{~b}$ & 8.93 \\
\hline $\mathrm{BCMF}$ & 17.0 * & 1.37 & $54.54 \mathrm{~b}$ & 1.02 & $0.252 \mathrm{c}$ & 0.052 & $0.24 \mathrm{~b}$ & 0.060 & $91.6 \mathrm{c}$ & 1.65 & $23.4 \mathrm{a} *$ & 1.50 \\
\hline BSWF & 20.16 & 3.97 & $29.84 \mathrm{a}^{*}$ & 2.69 & $0.042 \mathrm{a}^{*}$ & 0.017 & $0.055 \mathrm{a}^{*}$ & 0.006 & $62.88 \mathrm{a}$ & 3.42 & $58.83 c^{*}$ & 1.13 \\
\hline
\end{tabular}

a-c-statistically significant differences (LSD, $p<0.05$ ) within the groups of non-frozen or frozen cream; *-significant difference (LSD, $p<0.05$ ) between buttermilks of the same type from non-frozen or frozen cream.

The lower solubility at $\mathrm{pH}$ values lower than 5, observed for the creams of the present study, has also been reported in the literature [2], and it was attributed to the different contents of the samples in the insoluble at acidic $\mathrm{pH}$ casein and the mainly soluble whey protein. BSW contained a very low quantity of casein (Section 3.3, Table 3); therefore, the pH 4.6 did not affect its solubility.

The next functional property studied was ES (\%). ES was in all cases greater for $\mathrm{pH}$ 4.5. This $\mathrm{pH}$ effect can be connected to the presence of INSP. Keeping in mind that whey has a very low INSP (Table 3), someone would expect that BSW will present the same ES for both $\mathrm{pH}$ values. However, that only occurred for the buttermilk from frozen cream. Regarding the origin of the sweet cream, buttermilks from cow non-frozen and frozen creams led to less stable emulsions when prepared at $\mathrm{pH} 6.6$, having an ES of $\sim 16$ and 17\%, respectively. For $\mathrm{pH} 4.5$, the emulsion with the buttermilk from SW frozen cream was the less stable one (ES: $\sim 30 \%$ ). The emulsifying properties of buttermilks are attributed to their protein content as well as the presence of MFGM and their content of PL. Phan et al. [32] studied the emulsifying properties of MFGM materials and reported that the presence and concentration of all MFGM components (polar lipids, whey proteins, caseins, MFGM-specific proteins, and minerals), along with their possible interactions were critical for emulsion formation and stability. As reported earlier (Section 3.4.3), all buttermilks share statistically similar PL content. Moreover, BSW from both nonfrozen and frozen creams had the lowest protein content, whereas BSM had the greatest (Table 2). However, for frozen creams, as mentioned earlier, proteolysis-due to additional treatments of cream before churning, and changes on casein micelles over freezing-may have occurred. A reduction in the micelles' size affects the concentration of $\beta$-casein and thus, the surface tension. The total protein/PL ratio is often used to evaluate ES [70]. In the present study, this ratio was significantly affected only by the cream origin. It was statistically significantly higher $(p<0.05)$ in BSM; on average, it was $146 \pm 32.4$, $118 \pm 64.5$ and $94 \pm 49.5$ for BSM, BCM and BSW, respectively. No direct correlation of the various ratios of the samples of the present work to ES was found. On the same topic, the literature reports possible interactions between PL and proteins that stabilize or destabilize emulsions. For example, it was observed that interactions between proteins and PL at the air-water interfaces that they stabilize, are influenced by $\mathrm{pH}$, which led to different interfacial structure [71]. The emulsification technique is also critical for MFGM emulsions, as reported by Jukkola et al. [72]. The particles with greater size (Figure 3) of BCM may also play a role for the low emulsion stability it exhibited.

FA was also determined by measuring the volume of the created foam for $30 \mathrm{~mL}$ of sample. Overall, values ranged from 0.04 to 0.4 . In accordance to ES (\%), FA was, for most of the samples, greater for $\mathrm{pH}$ 4.5. BSW from frozen cream (BSWF), presented a distinctive 
low FA value for both $\mathrm{pH}$ values, i.e., 0.042 and 0.055 for $\mathrm{pH} 6.6$ and 4.6, respectively, while they exhibited the highest FA when coming from a non-frozen cream (i.e., 0.327 and 0.375 for $\mathrm{pH} 6.6$ and 4.6, respectively). FA is related to a number of factors like the proteins solubility, size, flexibility and denaturation, the surface charges and its hydrophobicity, as well as the fat content of the buttermilks. Fat-protein interactions are known to decrease the FA of a protein solution, due to the fat's amphiphilic nature and ability to displace the protein from the surface [73]. The PL content is another parameter affecting the creation of foam. As mentioned previously, BSW had the lowest protein to PL ratio.

PS is positively correlated with FA; however, in the present work, high PS values were not accompanied by a great FA. Thus, other factors should be taken under account. Protein denaturation results in greater surface hydrophobicity due to the unfolding of the proteins. According to Townsend and Nakai [74], the unfolding of denatured proteins in order to interact with the air-water interface, and its extent is critical for FA. Its increase leads to increased FA. Moreover, the ratio of casein, whey and MFGM protein affects protein absorption at the interface [75]. As already mentioned, in the present study, denaturation induced by the thermal processing was observed in BSW. The changes occurring during the freezing and storage of the frozen cream should also be taken under consideration.

As a step towards better understanding of our findings, multiple variable analysis was performed and exhibited interesting correlations between various protein-related indices and the studied functional properties (Table 8). WSN and its major constituents $\alpha$-LA and $\beta$-LG were significantly correlated with all measured properties, with the exception of FA. To further investigate these correlations, a differential assessement was performed. Subsets of correlations are presented in Table 8 . The NF subset did not include buttermilks from frozen creams to avoid the effect of changes occurred due to storage conditions. The SC subset did not include BSW to exclude any possible inteference of its totally different protein profile.

From Table 8, is evident that FA of buttermilks was not correlated statistically significantly with the nitrogenous fractions in contrast to viscosity and PS. The viscosity of the subset SC was correlated significantly with INSP, that is, mostly casein, since casein is present in the form of particles at native $\mathrm{pH}$ or as aggregates forming under acidic conditions. According to the linear correlation coefficients (Table 8), the INSP was very important for the PS of the various types of buttermilks at both $\mathrm{pH}$ values. This is an expected correlation due to the well-known behaviour of casein.

The only significant correlation of ES (\%) with the INSP - in which casein predominates -was observed for subset SC at both $\mathrm{pH}$ values (Table 8). It can be assigned to the emulsification ability of caseins, in particular, that of $\beta$-casein [76]. Kim et al. [77] found that the concentration of $\beta$-LG correlated strongly and positively with the functional properties of whey protein concentrates; whereas, significant correlations with other whey proteins were not observed. Casein and whey proteins showed no synergistic effect to interface and emulsifying properties and competitive adsorption of $\beta$-casein and $\beta$-LG takes place [76,78]. In particular, $\beta$-casein directly reduces the surface tension at the interfaces, the serum proteins contribute to the formation of a "tight" viscoelastic structure at the interfaces enhancing stability, while the glycoproteins and PL of the membrane contribute with their amphiphilic structures [3]. SM contains more casein and $\beta$-casein contributes more to sheep casein fraction compared with its cow counterpart. The abundance of $\beta$-casein and $\beta$-LG in SM $[34,35]$ can explain the significantly higher ES of BSM than that of BCM (Table 7). The correlation between ES and INSP was more intense at $\mathrm{pH} 4.5$ than in native $\mathrm{pH}$ 6.6. Caseins in the micellar form, as happens at $\mathrm{pH}$ 6.6, are less surface active because the hydrophobic moieties are burned on the inside of the structure [70]. 
Table 8. Linear correlation coefficients between nitrogenous fractions and functional properties of buttermilks. V—viscosity (mPa.s); ES—emulsion stability (\%); FA—foaming ability; PS—protein solubility (\%); INSP—protein insoluble at $\mathrm{pH} 4.6$; WSN—(water)-soluble nitrogen at $\mathrm{pH} 4.6$; $\beta$-LGnative $\beta$-lactoglobulin; $\alpha$-LA-native $\alpha$-lactalbumin; NF-group of buttermilks from non-frozen cream; SC-group of buttermilks from sweet cream.

\begin{tabular}{|c|c|c|c|c|c|c|}
\hline Properties & & INSP, \% & WSN, \% & $\alpha-\mathrm{LA}, \mathrm{mg} / \mathrm{L}$ & $\beta-\mathrm{LG}, \mathrm{mg} / \mathrm{L}$ & $\beta-\mathrm{LG} / \alpha-\mathrm{LA}$ \\
\hline \multirow[t]{3}{*}{ V-pH 6.6} & total $^{1}$ & -0.03 & -0.73 & -0.89 & -0.91 & -0.71 \\
\hline & $\mathrm{NF}^{2}$ & 0.08 & -0.78 & -0.86 & -0.90 & -0.71 \\
\hline & $\mathrm{SC}^{3}$ & -0.89 & -0.74 & -0.90 & -0.92 & -0.76 \\
\hline \multirow[t]{3}{*}{$\mathrm{V}-\mathrm{pH} 4.5$} & total & 0.18 & -0.74 & -0.83 & -0.89 & -0.73 \\
\hline & NF & 0.22 & -0.77 & -0.82 & -0.81 & -0.64 \\
\hline & SC & -0.83 & -0.64 & -0.81 & -0.86 & -0.74 \\
\hline \multirow{3}{*}{ ES-pH 6.6} & total & 0.03 & 0.50 & 0.41 & 0.58 & 0.64 \\
\hline & NF & 0.20 & 0.72 & 0.70 & 0.88 & 0.84 \\
\hline & SC & 0.66 & 0.67 & 0.62 & 0.78 & 0.81 \\
\hline \multirow[t]{3}{*}{ ES-pH 4.5} & total & 0.18 & -0.74 & -0.83 & -0.89 & -0.73 \\
\hline & NF & 0.22 & -0.77 & -0.82 & -0.81 & -0.64 \\
\hline & SC & -0.83 & -0.64 & -0.81 & -0.86 & -0.74 \\
\hline \multirow[t]{3}{*}{ FA-pH 6.6} & total & 0.12 & -0.21 & -0.27 & -0.36 & -0.32 \\
\hline & $\mathrm{NF}$ & -0.60 & 0.58 & 0.33 & 0.28 & 0.20 \\
\hline & SC & -0.32 & -0.32 & -0.41 & -0.35 & -0.19 \\
\hline \multirow[t]{3}{*}{ FA-pH 4.5} & total & 0.24 & -0.14 & 0.01 & -0.18 & -0.28 \\
\hline & $\mathrm{NF}$ & -0.44 & 0.24 & 0.17 & 0.10 & 0.03 \\
\hline & SC & 0.05 & 0.03 & -0.41 & 0.05 & -0.10 \\
\hline \multirow[t]{3}{*}{ PS-pH 6.6} & total & 0.71 & -0.71 & -0.52 & -0.59 & -0.51 \\
\hline & NF & 0.85 & -0.64 & -0.45 & -0.25 & -0.03 \\
\hline & SC & -0.26 & -0.21 & -0.18 & -0.14 & -0.09 \\
\hline \multirow[t]{3}{*}{ PS-pH 4.5} & total & -0.76 & 0.83 & 0.62 & 0.68 & 0.62 \\
\hline & NF & -0.89 & 0.84 & 0.51 & 0.47 & 0.36 \\
\hline & SC & 0.55 & 0.44 & 0.61 & 0.50 & 0.31 \\
\hline
\end{tabular}

${ }^{1}$ _all experimental buttermilks from non-frozen and frozen creams; ${ }^{2}$-buttermilks from non-frozen creams 3 _buttermilks from sweet sheep and cow cream.

\section{Conclusions}

Under similar manufacturing conditions, BSM was more advantageous compared with its cow counterpart in regard to protein content and profile, biofunctional potential and functional properties. Moreover, the churning of frozen sweet sheep cream had marginal effects on the properties and behaviour of buttermilk, which is of great importance considering the limited production period of SM. The properties of buttermilk from SW were differentiated due to the predominance of lactose and soluble proteins. According to the results, buttermilk from the further exploitation of SW may have specific applications, e.g., as an ingredient in low-pH food formulae. The findings of the present study exhibited the potential of SM by-products and can be the basis for new research efforts on this topic.

Author Contributions: Conceptualization, G.M.; methodology, L.S., V.E. and G.M.; formal analysis, L.S. and P.E.I.; investigation, L.S., V.E., P.E.I. and G.M.; writing-original draft preparation, L.S., V.E. and G.M.; writing - review and editing, G.M.; visualization, L.S., V.E., P.E.I. and G.M.; supervision, G.M. and V.E.; funding acquisition, G.M. All authors have read and agreed to the published version of the manuscript.

Funding: This research project was co-financed by Greece and the European Union (European Social Fund) through the Operational Program «Human Resources Development, Education and Lifelong Learning 2014-2020» and the Program encoded EDBM103, entitled "Support for researchers with an emphasis on young researchers-cycle B", in the context of the project "The study of the properties of sheep's buttermilk as a first step for its utilization" (MIS 5048555). 
Data Availability Statement: The data is presented in the manuscript.

Acknowledgments: The excellent support given during the analyses by the students Georgia Mouzakioti, Maria Kotsoglou, Georgios Choletsidis and Christos Tsakonas is highly appreciated. The authors thank Theodoros Paschos for the technical support during the preparation of buttermilks.

Conflicts of Interest: The authors declare no conflict of interest. The funders had no role in the design of the study; in the collection, analyses, or interpretation of data; in the writing of the manuscript, or in the decision to publish the results.

\section{Abbreviations}

\begin{tabular}{|c|c|}
\hline$\alpha-\mathrm{LA}$ & native $\alpha$-lactalbumin \\
\hline$\beta-\mathrm{LG}$ & $\beta$-lactoglobulin \\
\hline AAS & atomic absorption spectrometric method \\
\hline ANOVA & analysis of variance \\
\hline $\mathrm{BCM}$ & buttermilk from cow milk sweet cream \\
\hline BCMPF & buttermilk from CM-pasteurized and frozen cream \\
\hline BCMTF & buttermilk from CM-thermized and frozen cream \\
\hline BSM & buttermilk from sheep milk sweet cream \\
\hline BSMPF & buttermilk from sheep_-pasteurized and frozen cream \\
\hline BSMTF & buttermilk from sheep-thermized and frozen cream \\
\hline BSW & buttermilk from sheep whey cream \\
\hline BSWPF & buttermilk from sheep whey_pasteurized and frozen cream \\
\hline BSWTF & buttermilk from sheep whey-thermized and frozen cream \\
\hline CA & chelating activity \\
\hline $\mathrm{CM}$ & cow milk \\
\hline CMP & caseinomacropeptide \\
\hline DPPH & 2,2-diphenyl-1-picrylhydrazyl \\
\hline EDTA & ethylenediaminetetraacetic acid \\
\hline $\mathrm{ES}$ & $\%$ emulsion stability \\
\hline $\mathrm{F}$ & frozen cream \\
\hline FA & foaming ability \\
\hline INSP & protein insoluble at $\mathrm{pH} 4.6$ \\
\hline LA & lactic acid \\
\hline LSD & least significance difference \\
\hline MAS & molecular absorption spectrometry \\
\hline MFG & milk fat globule \\
\hline MFGM & milk fat globule membrane \\
\hline $\mathrm{N}$ & nitrogen \\
\hline NF & non-frozen cream \\
\hline $\mathrm{P}$ & pasteurized cream \\
\hline PL & phospholipids \\
\hline PVDF & poly(vinylidene fluoride) (filter) \\
\hline PS & $\%$ protein solubility \\
\hline RP-HPLC & reversed-phase high-performance liquid chromatography \\
\hline RSA & radical scavenging activity \\
\hline sd & standard deviation \\
\hline se & standard error \\
\hline SM & sheep milk \\
\hline SNF & non-fat solids \\
\hline SW & sheep cheese whey \\
\hline $\mathrm{T}$ & thermized cream \\
\hline $\mathrm{TN}$ & total nitrogen \\
\hline WSN & water-soluble nitrogen \\
\hline
\end{tabular}




\section{References}

1. Walstra, P.; Wouters, J.T.M.; Geurts, T.J. Dairy Science and Technology, 2nd ed.; CRC Press, Taylor and Francis Group: Boca Raton, FL, USA, 2006; pp. 467-495. [CrossRef]

2. Sodini, I.; Morin, P.; Olabi, A.; Jiménez-Flores, R. Compositional and functional properties of buttermilk: A comparison between sweet, sour, and whey buttermilk. J. Dairy Sci. 2006, 89, 525-536. [CrossRef]

3. Vanderghem, C.; Bodson, P.; Danthine, S.; Paquot, M.; Deroanne, C.; Blecker, C. Milk Fat Globule Membrane and Buttermilks: From Composition to Valorization. Biotechnol. Agron. Soc. Environ. 2010, 14, 485-500. Available online: https://www.cabdirect. org/cabdirect/abstract/20103309796 (accessed on 31 January 2022).

4. Ali, A.H. Current knowledge of buttermilk: Composition, applications in the food industry, nutritional and beneficial health characteristics. Int. J. Dairy Technol. 2019, 72, 169-182. [CrossRef]

5. Gassi, J.Y.; Famelart, M.H.; Lopez, C. Heat treatment of cream affects the physicochemical properties of sweet buttermilk. Dairy Sci. Technol. 2008, 88, 369-385. [CrossRef]

6. Dewettinck, K.; Rombaut, R.; Thienpont, N.; Le, T.T.; Messens, K.; Van Camp, J. Nutritional and technological aspects of milk fat globule membrane material. Int. Dairy J. 2008, 18, 436-457. [CrossRef]

7. Lopez, C. Milk fat globules enveloped by their biological membrane: Unique colloidal assemblies with a specific composition and structure. Curr. Opin. Colloid Interface Sci. 2011, 16, 391-404. [CrossRef]

8. Arranz, E.; Corredig, M. Invited review: Milk phospholipid vesicles, their colloidal properties, and potential as delivery vehicles for bioactive molecules. J. Dairy Sci. 2017, 100, 4213-4222. [CrossRef]

9. Singh, H.; Gallier, S. Nature's complex emulsion: The fat globules of milk. Food Hydrocoll. 2017, 68, 81-89. [CrossRef]

10. Bernard, L.; Bonnet, M.; Delavaud, C.; Delosière, M.; Ferlay, A.; Fougère, H.; Graulet, B. Milk fat globule in ruminant: Major and minor compounds, nutritional regulation and differences among species. Eur. J. Lipid Sci. Technol. 2018, 120, 1700039. [CrossRef]

11. Romeih, E.A.; Moe, K.M.; Skeie, S. The influence of fat globule membrane material on the microstructure of low-fat Cheddar cheese. Int. Dairy J. 2012, 26, 66-72. [CrossRef]

12. Verardo, V.; Gómez-Caravaca, A.M.; Arráez-Román, D.; Hettinga, K. Recent advances in phospholipids from colostrum, milk and dairy by-products. Int. J. Mol. Sci. 2017, 18, 173-195. [CrossRef]

13. Goudédranche, H.; Fauquant, J.; Maubois, J.L. Fractionation of globular milk fat by membrane microfiltration. Lait 2000, 80, 93-98. [CrossRef]

14. Wong, P.Y.Y.; Kitts, D.D. A comparison of the buttermilk solids functional properties to nonfat dried milk, soy protein isolate, dried egg white, and egg yolk powders. J. Dairy Sci. 2003, 86, 746-754. [CrossRef]

15. Wong, P.Y.Y.; Kitts, D.D. Chemistry of buttermilk solid antioxidant activity. J. Dairy Sci. 2003, 86, 1541-1547. [CrossRef]

16. Ripollés, D.; Parrón, J.A.; Calvo, M.; Pérez, M.D.; FitzGerald, R.J.; Sánchez, L. Antioxidant activity of co-products from milk fat processing and their enzymatic hydrolysates obtained with different proteolytic preparations. Int. Dairy J. 2016, 60, 70-77. [CrossRef]

17. Contarini, G.; Povolo, M. Phospholipids in milk fat: Composition, biological and technological significance, and analytical strategies. Int. J. Mol. Sci. 2013, 14, 2808-2831. [CrossRef]

18. Conway, V.; Gauthier, S.F.; Pouliot, Y. Buttermilk: Much more than a source of milk phospholipids. Anim. Front. 2014, 4, 44-51. [CrossRef]

19. Le Huërou-Luron, I.; Lemaire, M.; Blat, S. Health benefits of dairy lipids and MFGM in infant formula. OCL 2018, 25, D306. [CrossRef]

20. Fontecha, J.; Brink, L.; Wu, S.; Pouliot, Y.; Visioli, F.; Jiménez-Flores, R. Sources, production, and clinical treatments of milk fat globule membrane for infant nutrition and well-being. Nutrients 2020, 12, 1607. [CrossRef]

21. Govindasamy-Lucey, S.; Lin, T.; Jaeggi, J.J.; Johnson, M.E.; Lucey, A. Influence of condensed sweet cream buttermilk on the manufacture, yield, and functionality of pizza cheese. J. Dairy Sci. 2006, 89, 454-467. [CrossRef]

22. Hickey, C.D.; Diehl, B.W.K.; Nuzzo, M.; Scholz, D.; Millqvist-Feurby, A.; Wilkinson, M.G.; Sheehan, J.J. Influence of buttermilk powder or buttermilk addition on phospholipid content, chemical and bio-chemical composition and bacterial viability in cheddar style-cheese. Food Res. Int. 2017, 102, 748-758. [CrossRef]

23. Hickey, C.D.; O'Sullivan, M.G.; Davis, J.; Scholz, D.; Kilcawley, K.N.; Wilkinson, M.G.; Sheehan, J.J. The effect of buttermilk or buttermilk powder addition on functionality, textural, sensory and volatile characteristics of cheddar-style cheese. Food Res. Int. 2018, 103, 468-477. [CrossRef]

24. Sakkas, L.; Spiliopoulos, M.; Moatsou, G. Partial substitution of sheep and goat milks of various fat contents by the respective sweet buttermilks: Effect of cream heat treatment. LWT 2020, 133, 109926. [CrossRef]

25. Sakkas, L.; Alatini, E.; Moatsou, G. Use of sweet sheep buttermilk in the manufacture of reduced-fat sheep milk cheese. Int. Dairy J. 2021, 120, 105079. [CrossRef]

26. Morin, P.; Jiménez-Flores, R.; Pouliot, Y. Effect of processing on the composition and microstructure of buttermilk and its milk fat globule membranes. Int. Dairy J. 2007, 17, 1179-1187. [CrossRef]

27. Morin, P.; Pouliot, Y.; Britten, M. Effect of buttermilk made from creams with different heat treatment histories on properties of rennet gels and model cheeses. J. Dairy Sci. 2008, 91, 871-882. [CrossRef]

28. Gauvin, M.P.; Pouliot, Y.; Britten, M. Rennet coagulation properties of milk in the presence of MFGM fragments isolated from raw- and pasteurised-cream buttermilk. Int. Dairy J. 2018, 85, 153-158. [CrossRef] 
29. Olabi, A.; Jinjarak, S.; Jiménez-Flores, R.; Walker, J.H.; Daroub, H. Compositional and sensory differences of products of sweetcream and whey buttermilk produced by microfiltration, diafiltration, and supercritical $\mathrm{CO}_{2}$. J. Dairy Sci. 2015, 98, 3590-3598. [CrossRef]

30. Morin, P.; Pouliot, Y.; Jiménez-Flores, R. A comparative study of the fractionation of regular buttermilk and whey buttermilk by microfiltration. J. Food. Eng. 2006, 77, 521-528. [CrossRef]

31. Jinjarak, S.; Olabi, A.; Jiménez-Flores, R.; Sodini, I.; Walker, J.H. Sensory evaluation of whey and sweet cream buttermilk. J. Dairy Sci. 2006, 89, 2441-2450. [CrossRef]

32. Phan, T.T.Q.; Le, T.T.; Van der Meeren, P.; Dewettinck, K. Comparison of emulsifying properties of milk fat globule membrane materials isolated from different dairy by-products. J. Dairy Sci. 2014, 97, 4799-4810. [CrossRef] [PubMed]

33. Claeys, W.L.; Verraes, C.; Cardoen, S.; De Block, J.; Huyghebaert, A.; Raes, K.; Dewettinck, K.; Herman, L. Consumption of raw or heated milk from different species: An evaluation of the nutritional and potential health benefits. Food Control 2014, 42, 188-201. [CrossRef]

34. Moatsou, G.; Sakkas, L. Sheep milk components: Focus on nutritional advantages and biofunctional potential. Small Rumin. Res. 2019, 180, 86-99. [CrossRef]

35. Moatsou, G. Milk composition and properties: Interspecies comparison. In Understanding and Improving the Functional and Nutritional Properties of Milk; Huppertz, T., Vasiljevic, T., Eds.; Burleigh Dodds Science Publishing Limited: Sawston, Cambridge UK, 2022; in press.

36. Hamad, M.N.; Ismail, M.M.; El-Menawy, R.K.A. Chemical, rheological, microbial and microstructural characteristics of Jameed made from sheep, goat and cow buttermilk or skim milk. Am. J. Food Sci. Nutr. Res. 2016, 3, 46-55.

37. Lamothe, S.; Robitaille, G.; St-Gelais, D.; Britten, M. Butter making from caprine creams: Effect of washing treatment on phospholipids and milk fat globule membrane proteins distribution. J. Dairy Res. 2008, 75, 439-443. [CrossRef]

38. Parrón, J.A.; Ripollés, D.; Navarro, F.; Ramos, S.J.; Pérez, M.D.; Calvo, M.; Sánchez, L. Effect of high pressure treatment on the antirotaviral activity of bovine and ovine dairy by-products and bioactive milk proteins. Innov. Food Sci. Emerg. Technol. 2018, 48 , 265-273. [CrossRef]

39. Parrón, J.A.; Ripollés, D.; Pérez, M.D.; Calvo, M.; Rasmussen, J.T.; Sánchez, L. Antirotaviral activity of bovine and ovine dairy byproducts. J. Agric. Food Chem. 2017, 65, 4280-4288. [CrossRef]

40. Parrón, J.A.; Ripollés, D.; Ramos, S.J.; Pérez, M.D.; Semen, Z.; Rubio, P.; Calvo, M.; Sánchez, L. Antirotaviral potential of lactoferrin from different origin: Effect of thermal and high pressure treatments. Biometals 2018, 31, 343-355. [CrossRef]

41. Moatsou, G.; Moschopoulou, E.; Zoidou, E.; Kamvysi, A.; Liaskou, D.; Tsigkou, V.; Sakkas, L. Changes in native whey protein content, gel formation, and endogenous enzyme activities induced by flow-through heat treatments of goat and sheep milk. Dairy 2021, 2, 410-421. [CrossRef]

42. ISO/IDF. Milk—Determination of Fat Content; International Standard IDF 226/ISO 2446:2008; International Dairy Federation: Brussels, Belgium, 2008.

43. ISO/IDF. Milk and Milk Products_Determination of Calcium, Sodium, Potassium and Magnesium Contents-Atomic Absorption Spectrometric Method; International Standard IDF 119/ISO 8070:2007; International Dairy Federation: Brussels, Belgium, 2007.

44. ISO/IDF. Cheese and Processed Cheese Products—Determination of Total Phosphorus Content-Molecular Absorption Spectrometric Method; International Standard IDF 33/ISO 9874:2010; International Dairy Federation: Brussels, Belgium, 2010.

45. Moschopoulou, E.; Sakkas, L.; Zoidou, E.; Theodorou, G.; Sgouridou, E.; Kalathaki, C.; Liarakou, A.; Chatzigeorgiou, A.; Politis, I.; Moatsou, G. Effect of milk kind and storage on the biochemical, textural and biofunctional characteristics of set-type yoghurt. Int. Dairy J. 2018, 77, 47-55. [CrossRef]

46. Conway, V.; Gauthier, S.F.; Pouliot, Y. Antioxidant activities of buttermilk proteins, whey proteins, and their enzymatic hydrolysates. J. Agric. Food Chem. 2013, 61, 364-372. [CrossRef]

47. Huang, X.; Kakuda, Y.; Cui, W. Hydrocolloids in emulsions: Particle size distribution and interfacial activity. Food Hydrocoll. 2001, 15, 533-542. [CrossRef]

48. Park, Y.W.; Juárez, M.; Ramos, M.; Haenlein, G.F.W. Physico-chemical characteristics of goat and sheep milk. Small Rumin. Res. 2007, 68, 88-113. [CrossRef]

49. Morin, P.; Jiménez-Flores, R.; Pouliot, Y. Effect of temperature and pore size on the fractionation of fresh and reconstituted buttermilk by microfiltration. J. Dairy Sci. 2004, 87, 267-273. [CrossRef]

50. Barry, K.M.; Dinan, T.G.; Murray, B.A.; Kelly, P.M. Comparison of dairy phospholipid preparative extraction protocols in combination with analysis by high performance liquid chromatography coupled to a charged aerosol detector. Int. Dairy J. 2016, 56, 179-185. [CrossRef]

51. Lambert, S.; Leconte, N.; Blot, M.; Rousseau, F.; Robert, B.; Camier, B.; Gassi, J.Y.; Cauty, C.; Lopez, C.; Gésan-Guiziou, G. The lipid content and microstructure of industrial whole buttermilk and butter serum affect the efficiency of skimming. Food Res. Int. 2016, 83, 121-130. [CrossRef]

52. Costa, M.R.; Elias-Argote, X.E.; Jiménez-Flores, R.; Gigante, M.L. Use of ultrafiltration and supercritical fluid extraction to obtain a whey buttermilk powder enriched in milk fat globule membrane phospholipids. Int. Dairy J. 2010, 20, 598-602. [CrossRef]

53. Ye, A.; Singh, H.; Taylor, M.W.; Anema, S. Interactions of whey proteins with milk fat globule membrane proteins during heat treatment of whole milk. Lait 2004, 84, 269-283. [CrossRef] 
54. Ye, A.; Singh, H.; Oldfield, D.J.; Anema, S. Kinetics of heat-induced association of $\beta$-lactoglobulin and $\alpha$-lactalbumin with milk fat globule membrane in whole milk. Int. Dairy J. 2004, 14, 389-398. [CrossRef]

55. O'Connell, J.E.; Fox, P.F. Heat stability of buttermilk. J. Dairy Sci. 2000, 83, 1728-1732. [CrossRef]

56. Holzmüller, W.; Gmach, O.; Griebel, A.; Kulozik, U. Casein precipitation by acid and rennet coagulation of buttermilk: Impact of $\mathrm{pH}$ and temperature on the isolation of milk fat globule membrane proteins. Int. Dairy J. 2016, 63, 115-123. [CrossRef]

57. Ramachandra Rao, H.G.; Lewis, M.J.; Grandison, A.S. Effect of pH on flux during ultrafiltration of sweet whey and buttermilk. J. Dairy Res. 1995, 62, 441-449. [CrossRef]

58. Cichosz, G.; Czeczot, H.; Ambroziak, A.; Bielecka, M.M. Natural antioxidants in milk and dairy products. Int. J. Dairy Technol. 2017, 70, 165-178. [CrossRef]

59. Khan, I.T.; Nadeem, M.; Imran, M.; Ullah, R.; Ajmal, M.; Jaspal, M.H. Antioxidant properties of milk and dairy products: A comprehensive review of the current knowledge. Lipids Health Dis. 2019, 18, 41. [CrossRef]

60. Rombaut, R.; Camp, J.V.; Dewettinck, K. Phospho- and sphingolipid distribution during processing of milk, butter and whey. Int J. Food Sci. Technol. 2006, 41, 435-443. [CrossRef]

61. Verardo, V.; Gómez-Caravaca, A.M.; Gori, A.; Losi, G.; Caboni, M.F. Bioactive lipids in the butter production chain from parmigianoreggiano cheese area. J. Sci. Food Agric. 2013, 93, 3625-3633. [CrossRef]

62. Konrad, G.; Kleinschmidt, T.; Lorenz, C. Ultrafiltration of whey buttermilk to obtain a phospholipid concentrate. Int. Dairy J. 2013, 30, 39-44. [CrossRef]

63. Corredig, M.; Roesch, R.R.; Dalgleish, D.G. Production of a novel ingredient from buttermilk. J. Dairy Sci. 2003, 86, 2744-2750. [CrossRef]

64. Holzmüller, W.; Gmach, O.; Griebel, A.; Kulozik, U. Isolation of milk fat globule membrane (MFGM) material by coagulation and diafiltration of buttermilk. Int. Dairy J. 2016, 63, 115-123. [CrossRef]

65. Barry, K.M.; Dinan, T.G.; Kelly, P.M. Selective enrichment of dairy phospholipids in a buttermilk substrate through investigation of enzymatic hydrolysis of milk proteins in conjunction with ultrafiltration. Int. Dairy J. 2017, 68, 80-87. [CrossRef]

66. Barry, K.M.; Dinan, T.G.; Kelly, P.M. Pilot scale production of a phospholipid-enriched dairy ingredient by means of an optimised integrated process employing enzymatic hydrolysis, ultrafiltration and super-critical fluid extraction. Innov. Food Sci. Emerg. Technol. 2017, 41, 301-306. [CrossRef]

67. Sprick, B.; Linghu, Z.; Amamcharla, J.K.; Metzger, L.E.; Smith, J.S. Selective extraction of phospholipids from whey protein phospholipid concentrate using supercritical carbon dioxide and ethanol as a co-solvent. J. Dairy Sci. 2019, 102, 10855-10866. [CrossRef] [PubMed]

68. Spitsberg, V.L.; Ivanov, L.; Shritz, V. Recovery of milk fat globule membrane (MFGM) from buttermilk: Effect of Ca-binding salts. J. Dairy Res. 2019, 86, 374-376. [CrossRef] [PubMed]

69. Sakkas, L.; Pappas, C.S.; Moatsou, G. FT-MIR Analysis of water-soluble extracts during the ripening of sheep milk cheese with different phospholipid content. Dairy 2021, 2, 530-541. [CrossRef]

70. Roesch, R.R.; Rincon, A.; Corredig, M. Emulsifying properties of fractions prepared from commercial buttermilk by microfiltration. J. Dairy Sci. 2004, 87, 4080-4087. [CrossRef]

71. Caro, A.L.; Niño, M.R.R.; Patino, J.M.R. The effect of $\mathrm{pH}$ on structural, topographical, and rheological characteristics of $\beta$ casein-DPPC mixed monolayers spread at the air-water interface. Colloids Surf. A Physicochem. Eng. Aspects 2009, 332, 180-191. [CrossRef]

72. Jukkola, A.; Partanen, R.; Xiang, W.; Heino, A.; Rojas, O.J. Food emulsifiers based on milk fat globule membranes and their interactions with calcium and casein phosphoproteins. Food Hydrocoll. 2019, 94, 30-37. [CrossRef]

73. Vaghela, M.N.; Kilara, A. Foaming and emulsifying properties of whey protein concentrates as affected by lipid composition. J. Food Sci. 1996, 61, 275-280. [CrossRef]

74. Townsend, A.A.; Nakai, S. Relationship between hydrophobicity and foaming characteristics of food proteins. J. Food Sci. 1983, 48, 588-594. [CrossRef]

75. Corredig, M.; Dalgleish, D.G. Buttermilk properties in emulsions with soybean oil as affected by fat globule membrane-derived proteins. J. Food Sci. 1998, 63, 476-480. [CrossRef]

76. Dickinson, E. Properties of emulsions stabilized with milk proteins: Overview of some recent developments. J. Dairy Sci. 1997, 80, 2607-2619. [CrossRef]

77. Kim, Y.A.; Chism, G.W.; Mangino, M.E. Determination of the beta-lactoglobulin, alpha-lactalbumin and bovine serum albumin of whey protein concentrates and their relationship to protein functionality. J. Food Sci. 1987, 52, 124-127. [CrossRef]

78. Britten, M.; Giroux, H.J. Use of a flow cell apparatus to determine the emulsifying properties of casein. J. Food Sci. 1990, 55, 1152-1156. [CrossRef] 